\title{
Muscle Yap Is a Regulator of Neuromuscular Junction Formation and Regeneration
}

\author{
๑Kai Zhao, ${ }^{1}$ Chengyong Shen, ${ }^{1,4}$ Yisheng Lu, ${ }^{1,5,6}$ Zhihui Huang, ${ }^{1,7}$ Lei Li, ${ }^{1}$ CChristopher D. Rand, ${ }^{8}$ Jinxiu Pan, ${ }^{1,2,3}$

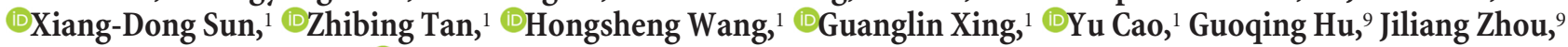 \\ Wen-Cheng Xiong, ${ }^{1,2,3}$ and $\oplus^{-L i n}$ Mei $^{1,2,3}$ \\ 'Department of Neuroscience and Regenerative Medicine, Medical College of Georgia, Augusta University, Augusta, Georgia 30912, ${ }^{2}$ Department of \\ Neurology, Medical College of Georgia, Augusta University, Augusta, Georgia 30912, ${ }^{3}$ Charlie Norwood Veterans Administration Medical Center, Augusta, \\ Georgia 30912, "Institute of Translational Medicine, First Affiliated Hospital of Zhejiang University, Hangzhou 310020, China, ${ }^{5}$ Department of Physiology, \\ School of Basic Medicine, Huazhong University of Science and Technology, Wuhan 430070, China, ${ }^{6}$ Institute of Brain Research, Collaborative Innovation \\ Center for Brain Science, Huazhong University of Science and Technology, Wuhan 430070, China, ${ }^{7}$ Institute of Hypoxia Medicine and Institute of \\ Neuroscience, Wenzhou Medical University, Wenzhou 325035, China, ${ }^{8}$ Aurora Scientific Inc., Aurora, Ontario L4G 1X6, Canada, and ${ }^{9}$ Department of \\ Pharmacology and Toxicology, Medical College of Georgia, Augusta University, Augusta, Georgia 30912
}

Yes-associated protein (Yap) is a major effector of the Hippo pathway that regulates cell proliferation and differentiation during development and restricts tissue growth in adult animals. However, its role in synapse formation remains poorly understood. In this study, we characterized Yap's role in the formation of the neuromuscular junction (NMJ). In $H S A-Y_{a p}{ }^{-1-}$ mice where Yap was mutated specifically in muscle cells, AChR clusters were smaller and were distributed in a broader region in the middle of muscle fibers, suggesting that muscle Yap is necessary for the size and location of AChR clusters. In addition, $H S A-Y a p^{-1-}$ mice also exhibited remarkable presynaptic deficits. Many AChR clusters were not or less covered by nerve terminals; miniature endplate potential frequency was reduced, which was associated with an increase in paired-pulse facilitation, indicating structural and functional defects. In addition, muscle Yap mutation prevented reinnervation of denervated muscle fibers. Together, these observations indicate a role of muscle Yap in NMJ formation and regeneration. We found that $\beta$-catenin was reduced in the cytoplasm and nucleus of mutant muscles, suggesting compromised $\beta$-catenin signaling. Both NMJ formation and regeneration deficits of $H S A-Y_{a p}{ }^{-1-}$ mice were ameliorated by inhibiting $\beta$-catenin degradation, further corroborating a role of $\beta$-catenin or Wnt-dependent signaling downstream of Yap to regulate NMJ formation and regeneration.

Key words: $\beta$-catenin; neuromuscular junction; regeneration; YAP

\section{Significance Statement}

This paper explored the role of Yes-associated protein (Yap) in neuromuscular junction (NMJ) formation and regeneration. Yap is a major effector of the Hippo pathway that regulates cell proliferation and differentiation during development and restricts tissue growth in adult animals. However, its role in synapse formation remains poorly understood. We provide evidence that muscle Yap mutation impairs both postsynaptic and presynaptic differentiation and function and inhibits NMJ regeneration after nerve injury, indicating a role of muscle Yap in these events. Further studies suggest compromised $\beta$-catenin signaling as a potential mechanism. Both NMJ formation and regeneration deficits of $H S A-Y a p^{-1-}$ mice were ameliorated by inhibiting $\beta$-catenin degradation, corroborating a role of $\beta$-catenin or Wnt-dependent signaling downstream of Yap to regulate NMJ formation and regeneration.

\section{Introduction}

The neuromuscular junction (NMJ) is a chemical synapse that conveys electric signal from motor neuron to skeletal muscle to

Received Sept. 19, 2016; revised Feb. 2, 2017; accepted Feb. 7, 2017.

Author contributions: L.M., K.Z., C.S., and W.-C.X. designed research; K.Z., C.S., Y.L., Z.H., J.P., X.-D.S., Z.T., H.W., L.L., Y.C., C.D.R., and G.X. performed research; J.P., G.H., and J.Z. contributed unpublished reagents/analytic tools; L.M., K.Z., C.S., Y.L., Z.H., X.-D.S., Z.T., H.W., L.L., C.D.R., and G.X. analyzed data; L.M., K.Z., and W.-C.X. wrote the paper. control contraction (Sanes and Lichtman, 2001; Wu et al., 2010; Tintignac et al., 2015). Improper NMJ formation and maintenance have been implicated in various neuromuscular disorders,
This work was supported in part by Grants from the National Institutes of Health and Veterans Affairs. L.M. is a Georgia Research Alliance Eminent Scholar in Neuroscience.

The authors declare no competing financial interests.

Correspondence should be addressed to Dr. Lin Mei, Department of Neuroscience and Regenerative Medicine, Medical College of Georgia, Augusta University, 1120 15th Street, Augusta, GA 30912. E-mail: Imei@augusta.edu. DOI:10.1523/JNEUROSCI.2934-16.2017

Copyright $\odot 2017$ the authors $\quad 0270-6474 / 17 / 373465-13 \$ 15.00 / 0$ 
such as myasthenia gravis, congenital myasthenic syndrome, and amyotrophic lateral sclerosis. Functional NMJ requires intimate interactions between motor nerve terminals, skeletal muscle fibers, and perisynaptic Schwann cells (Wu et al., 2010; Darabid et al., 2014). For example, neuronal agrin binds to low-density lipoprotein receptor-related protein 4 (Lrp4) and thus activates muscle-specific kinase (MuSK) in postsynaptic muscle fibers (DeChiara et al., 1996; Cohen et al., 1997; Sanes and Lichtman, 2001; Kim et al., 2008; Zhang et al., 2008; Tintignac et al., 2015). Ensuing intracellular signaling presumably via the adaptor protein Dok7 leads to postjunctional assembly, including AChR clustering (Phillips et al., 1991; Gautam et al., 1995; Okada et al., 2006; Bergamin et al., 2010; Wu et al., 2010; Tintignac et al., 2015). The agrin/Lrp4/MuSK signaling is critical not only for NMJ formation, but also for its maintenance (Barik et al., 2014b). On the other hand, ACh released from motor neurons, via muscle activation, suppresses AChR expression and disperses receptor clusters, involving Cdk5 kinase (Lin et al., 2001; Fu et al., 2005; Lin et al., 2005; Chen et al., 2007; Yang et al., 2011).

NMJ formation is also regulated by factors that are produced in muscle fibers (Oppenheim et al., 1995; Keller-Peck et al., 2001; Umemori et al., 2004; Fox et al., 2007; Baudet et al., 2008; Macpherson et al., 2015). Recently, evidence emerged that $\beta$-catenin in muscle fibers regulates motor neuron differentiation and neuromuscular transmission. Mutant mice without $\beta$-catenin in muscle die neonatally, with profound presynaptic deficits, such as mislocation of phrenic nerve primary branches, reduced synaptic vesicles, and impaired neuromuscular transmission, in addition to postsynaptic defects (Li et al., 2008). Moreover, expression of stable $\beta$-catenin in muscle cells also impairs presynaptic differentiation in mutant mice (Liu et al., 2012; Wu et al., 2012a). These observations suggest that $\beta$-catenin in muscle is critical for a retrograde pathway to direct nerve terminal development. In vivo rescue experiments indicate that the effect of $\beta$-catenin does not require its interaction with $\alpha$-catenin, but its transactivation domain, suggesting the involvement of transcriptional regulation, but not cell-adhesion function (Wu et al., 2015). One downstream factor may be Slit 2 whose transcription is regulated by $\beta$-catenin, and increasing its expression in the muscle diminishes presynaptic deficits in $\beta$-catenin mutant mice (Wu et al., 2015). However, how $\beta$-catenin is regulated in terms of NMJ formation is not well understood.

In this study, we characterized Yap's role in synapse formation and regeneration using the NMJ as a model. We demonstrated that mutant mice that lack Yap specifically in muscles formed larger NMJs that were distributed in a broader central region of the fibers. Remarkably, the mutant mice displayed deficits in structure and function of motor axon terminals. Muscle Yap mutation also prevented reinnervation of AChR clusters after denervation. We explored underlying mechanisms by which muscle Yap regulates NMJ formation and regeneration. Our results suggest that Yap in muscles regulates $\beta$-catenin signaling that has been shown to be critical for NMJ formation. Together, these observations uncover a previously unappreciated role of Yap in NMJ formation and regeneration.

\section{Materials and Methods}

Generation and genotyping of mouse lines. Yap ${ }^{f l o x / f l o x}\left(Y_{a p}{ }^{f / f}\right)$ mice (Zhang et al., 2010; Wang et al., 2014) (Jax catalog \#027929) were crossed with human skeletal actin (HSA) Cre mice (Jax catalog \#006149) (Miniou et al., 1999; Schwander et al., 2003) to generate HSA::Cre;Yap ${ }^{\text {f/f }}$ mice (referred as HSA-Yap ${ }^{-1-}$ hereafter). The background of the mice was $\mathrm{C} 57 \mathrm{BL} / 6$. Mice were housed in a room with a $12 \mathrm{~h}$ light/dark cycle and ad
Table 1. Gene-specific primers

\begin{tabular}{lll}
\hline Name & Forward $\left(5^{\prime}\right.$-3 $\left.^{\prime}\right)$ & Reverse $\left(5^{\prime}\right.$ - $\left.^{\prime}{ }^{\prime}\right)$ \\
\hline Slit2 & GGCAGACACTGTCCCTATCG & ATCTGTCTTCGTGATCCTCGTGA \\
Bdnf & AGGCCAACTGAAGCAGTATTTCTAC & GAACATACGATTGGGTAGTTCGG \\
Gdnf & CTGACTTGGGTTGGGCTATGA & TGCCTGGCCTACTTTGTCACTT \\
Gdf5 & GCCCACAAACCACGCAGTC & GCCACAAGATTCCACGACCAT \\
Fgf7 & GAAGACTGTTCTGTCGCACCCA & ATTGCATAGAGTTCCCTTCCTTGT \\
Fgf10 & GCCACCAACTGCTCTTCTTCC & GCTGACCTTGCCGTTCTTCTC \\
Fgf22 & GCTTCTATGTGGCCATGAATCG & AGACCAAGACTGGCAGGAAGTGT \\
Bmp4 & GAGGAGTTTCCATCACGAAG & TCTCCACTCCCTTGAGGTAA \\
Myf5 & ACCACCACCAACCCTAACCAG & ACCAGACAGGGCTGTTACATTCA \\
Myog & GCGGCTGCCTAAAGTGGAGA & GGAGGCGCTGTGGGAGTTG \\
MyoD & GGCTACGACACCGCCTACTACA & TGTGGAGATGCGCTCCACTAT \\
GAPDH & AAGGTCATCCCAGAGCTGAA & CTGCTTCACCACCTTCTTGA \\
\hline
\end{tabular}

libitum access to water and rodent chow diet (Diet 7097, Harlan Teklad). Unless otherwise indicated, control mice were littermate $Y a p^{f / f}$ mice that showed no NMJ deficits compared with wild-type. Mice of either sex were studied. Animal experimental procedures were approved by the Institutional Animal Care and Use Committee at Augusta University.

Reagents and antibodies. Chemicals were purchased from Sigma-Aldrich unless otherwise indicated. CF568 $\alpha$-bungarotoxin ( $\alpha$-BTX, \#00006, 1:1000 for staining) was purchased from Biotium. Antibodies used were Yap (WH0010413M1, 1:1000 for Western blot) and laminin (\#041M4799, 1:200 for staining) from Sigma-Aldrich; $\beta$-catenin ( $\# 610154,1: 1000$ for Western blot) from BD Biosciences; $\delta$-catenin (1:1000 for Western blot) from Thermo Fisher; S100 $\beta$ (Z031129-2, 1:500 for staining) from Dako; SV2 (1:500 for Western blot and staining) and myosin Type I (A4.840, 1:500 for staining) from Developmental Studies Hybridoma Bank; GAPDH (NB 600501; 1:3000 for Western blot) from Novus; PARP (\#46D11, 1:1000 for Western blot); neurofilament (C28E10, 1:500 for staining); and synapsin (D12G5, 1:500 for Western blot and staining) from Cell Signaling Technology. AlexaFluor- 488 goat anti-rabbit IgG, AlexaFluor-488 goat anti-mouse IgG, and AlexaFluor-555 goat anti-rabbit IgG were described previously (Wu et al., 2012b). HRP-conjugated goat anti-rabbit IgG (32260), goat anti-mouse IgG (32230), and goat anti-rat $\operatorname{IgG}(31470)$ antibodies (1:4000 for Western blot) were from Pierce. Anti-agrin-C95 (1:500 for staining) was a gift provided by Dr. Markus Ruegg. Anti-MuSK and anti-AChR $\beta$ antibodies were described previously (Wu et al., 2012a; Barik et al., 2014b).

Immunofluorescence. Muscles were fixed with $4 \% \mathrm{PFA}$ in $\mathrm{PBS}$ at $4^{\circ} \mathrm{C}$ overnight, rinsed with $0.1 \mathrm{M}$ glycine in PBS for $30 \mathrm{~min}$, and incubated with the blocking buffer (5\% BSA, 2\% Triton X-100, 5\% goat serum in $\mathrm{PBS}$ ) for $2 \mathrm{~h}$ at room temperature. They were then incubated with primary antibodies in blocking buffer at $4^{\circ} \mathrm{C}$ overnight. After washing 3 times for $1 \mathrm{~h}$ each with 2\% Triton X-100 in PBS, the samples were incubated with fluorescent-labeled secondary antibodies in blocking buffer overnight at $4^{\circ} \mathrm{C}$. Muscle samples were then washed with $2 \%$ Triton X-100 in PBS 3 times for $1 \mathrm{~h}$ each and mounted with Vectashield mounting medium (H1200) and coverslip. For muscle cross-section staining, muscles were fixed with $4 \% \mathrm{PFA}$ in PBS at $4^{\circ} \mathrm{C}$ overnight. After dehydration by $30 \%$ sucrose at $4^{\circ} \mathrm{C}$ overnight, muscles were frozen at $-80^{\circ} \mathrm{C}$ in Cryo-embedding medium (Ted Pella) and cut into $30 \mu \mathrm{m}$ sections on a cryostat (HM550; Thermo Scientific). Sections were incubated with the blocking buffer for $2 \mathrm{~h}$ at room temperature and then with primary antibodies in the blocking buffer at $4^{\circ} \mathrm{C}$ overnight. After washing 3 times for $1 \mathrm{~h}$ each with $2 \%$ Triton X-100 in PBS at room temperature, the samples were incubated with fluorescent-labeled secondary antibodies in the blocking buffer overnight at $4^{\circ} \mathrm{C}$. The samples were mounted with Vectashield mounting medium. Z serial images were collected with a Zeiss confocal laser scanning microscope (LSM 700) and collapsed into a single image.

Western blot analysis. Western blot was performed as described previously (Barik et al., 2014b).

RT-PCR analysis. Total RNA was purified from gastrocnemius with Trizol (Invitrogen) and reverse transcribed to cDNAs with GoScript reverse transcription kit (Promega). cDNAs were used as template in qPCR in a $20 \mu \mathrm{l}$ reaction system containing SYBR GreenER qPCR mix with 
A

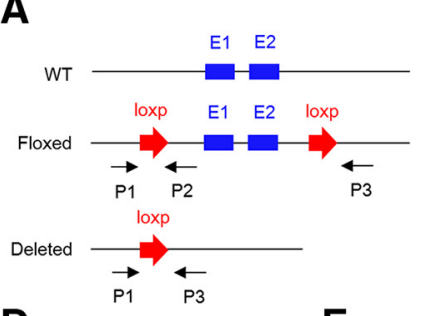

D

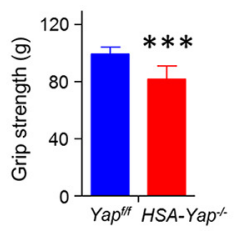

H

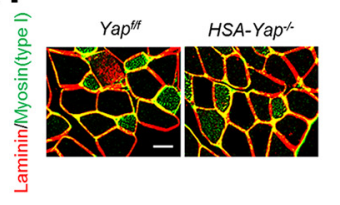

E
B
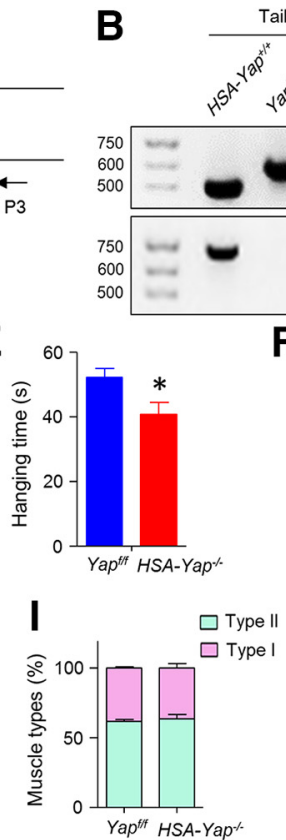

$\mathbf{F}$

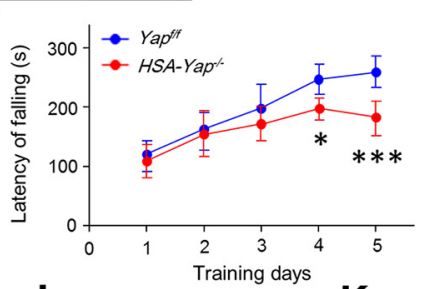

$\mathbf{J}$

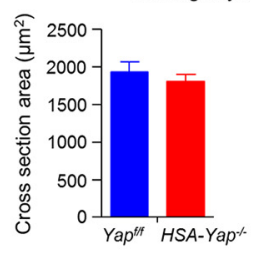

C

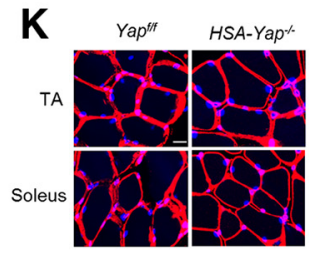

G
Muscle - Liver $\longrightarrow$ Heart $\longrightarrow$ Spinal cord

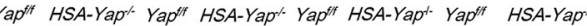
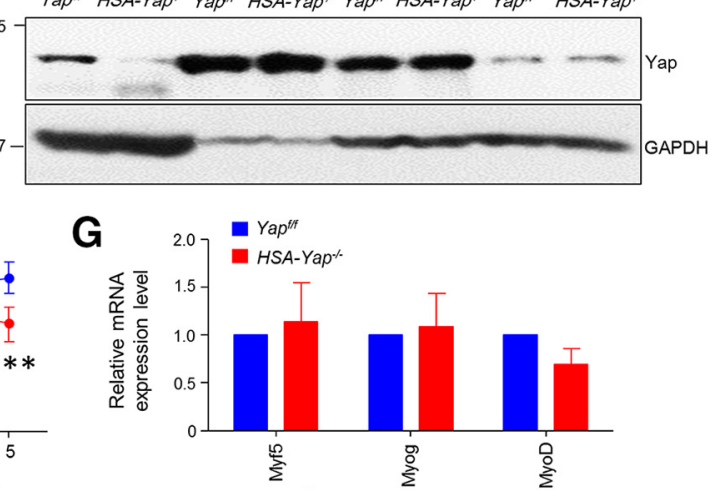

(1)

L

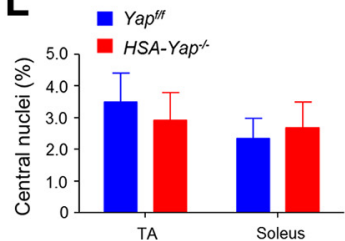

Figure 1. Decreased muscle strength in HSA-Yap ${ }^{-1-}$ mice. A, Schematic diagrams of WT, floxed, and deleted alleles of the mouse Yap gene. P1, P2, and P3 were genotyping primers. E1, Exon 1 ; E2, exon 2. B, Genotyping results of HSA-Yap ${ }^{+/+} ; \mathrm{Yap}^{\mathrm{fff}} ; \mathrm{Yap}^{\mathrm{f} /+} ; \mathrm{HSA}-\mathrm{Yap}^{-1-}$ mice. Tail and muscle DNA was isolated and subjected to PCR analysis. Arrows indicate bands expected for different genotypes. Molecular weight markers (in bp) are indicated on the left. C, Muscle-specific reduction of Yap. Homogenates of different tissues were subjected to Western blot with anti-Yap and GAPDH antibodies. D, Decreased grip strength of HSA-Yap ${ }^{-1-}$ mice. ${ }^{* * *} p=0.00061$ (unpaired $t$ test). $N=20$ mice per group. $E$, Reduced time in wire hanging test of HSA-Yap ${ }^{-l-}$ mice. ${ }^{*} p=0.012$ (unpaired $t$ test). $N=23$ mice per group. $\boldsymbol{F}$, Increased falling from Rotarod of HSA-Yap ${ }^{-1-}$ mice. ${ }^{*} p<0.05$ (two-way ANOVA). ${ }^{* * *} p<0.001$ (two-way ANOVA). $N=15$ mice per group. $\boldsymbol{G}$, Comparable levels of myogenic factor mRNA between control and mutant groups. $N=3$ or 4 mice per group. $\boldsymbol{H}$, Representative images of gastrocnemius cross sections. Scale bar, $20 \mu \mathrm{m}$. $\boldsymbol{I}$, Comparable muscle types between control and mutant mice. $N=5$ mice per group. $J$, No difference in cross section area of muscle fibers. $N=6$ mice per group. $K$, Similar nuclear distribution on TA and soleus muscle. Red represents laminin. Blue represents DAPI. Scale bar, $20 \mu \mathrm{m}$. L, Quantification of central nuclei percentage of $\boldsymbol{K}$. $N=5$ mice per group.

gene-specific primers (Table 1). PCR included an initial step at $95^{\circ} \mathrm{C}(3$ $\mathrm{min})$, followed by 40 cycles consisting of denaturation at $95^{\circ} \mathrm{C}(15 \mathrm{~s})$, annealing and extension at $60^{\circ} \mathrm{C}(60 \mathrm{~s})$. GAPDH was used as internal control.

Examination of motor function and muscle strength. Two-month-old mice were subjected to muscle grip strength and motor function tests. Muscle strength was measured by SR-1 hanging scale (American Weigh Scales) (Shen et al., 2013; Barik et al., 2014b). Briefly, mice were allowed with forelimbs to grasp a grid that was connected to a scale. Their tails were gently pulled until the grid was released by the forelimbs, and readings of the scale were recorded. Motor function was examined by Rotarod test, where mice were placed on rods that could rotate. After adaption at $4 \mathrm{rpm}$ for $2 \mathrm{~min}$, the rotation speed was increased to $40 \mathrm{rpm}$ (within $5 \mathrm{~min}$ ) to measure the latency time of mice to fall off from the rod. Mice were tested 3 times per day with $1 \mathrm{~h}$ interval, and averaged latency times were recorded. For wire hanging test, mice were placed on a $1.5 \mathrm{~mm}$-diameter wire, with hind limbs tied up, and measured the time remaining on the wire.

Electromyography and electrophysiological recording. Mice were anesthetized with ketamine and xylazine mixture $(100$ and $10 \mathrm{mg} / \mathrm{kg}$ body weight, respectively) on a $37^{\circ} \mathrm{C}$ heating pad. The stimulation needle electrode (TECA, 092-DMF25-S) was inserted near the sciatic nerve of the left thigh. The reference needle electrode was inserted into the Achilles tendon while the recording needle electrode was inserted into the middle of the left gastrocnemius. The reference and recording electrodes were connected to Axopatch 200B Amplifier (Molecular Devices). The stimulating electrode was connected to an isolator (AMPI, ISO-Flex). The stimulation of the sciatic nerve was triggered with a series of 10 stimuli at 1, 5, 10, 20, and $40 \mathrm{~Hz}$. Compound muscle action potentials (CMAPs) were recorded by Digidata 1322A and analyzed by Clampfit 9.2 software (Molecular Devices).

To study neuromuscular transmission, left hemi-diaphragm together with ribs and phrenic nerves were dissected, mounted on Sylgard gel, and perfused in oxygenated $\left(95 \% \mathrm{O}_{2}, 5 \% \mathrm{CO}_{2}\right)$ Ringer's solution $(137 \mathrm{~mm}$
$\mathrm{NaCl}, 5 \mathrm{~mm} \mathrm{KCl}, 12 \mathrm{~mm} \mathrm{NaHCO}, 1 \mathrm{~mm} \mathrm{NaH} \mathrm{PO}_{4}, 1 \mathrm{~mm} \mathrm{MgCl}, 2 \mathrm{~mm}$ $\mathrm{CaCl}_{2}, 11 \mathrm{~mm}$ D-glucose, $\mathrm{pH}$ 7.3) at room temperature. To record miniature endplate potentials (mEPPs), microelectrodes (CV203 BU HEADSTAGE, $20-40 \mathrm{M} \Omega$, filled with $3 \mathrm{M} \mathrm{KCl}$ ) connected to the Axopatch 200B Amplifier were inserted to the center of the muscle, with the resting membrane potential at -65 to $-80 \mathrm{mV}$. Five recordings were performed per diaphragm, each lasting 3-4 min. To record endplate potentials (EPPs) and paired-pulse ratios, phrenic nerve stubs were held by electrodes via vacuum sucking and stimulated by platinum wire inside electrodes. The electrodes were connected to the isolator, the amplifier and Digidata 1322A as described above. Recording was performed in the presence of $2.5 \mu \mathrm{M} \mu$-conotoxin to block action potentials and muscle contraction. Trigger signals ( $1 \mathrm{~ms}$ duration) were programmed using Clampex 9.2 software and delivered by the Digidata 1322A/isolator. Data were collected with Axopatch 200B Amplifier and Digidata 1322A and analyzed by Clamfit 9.2 software.

In vivo twitch and tetanic force measurement. Torque muscle tension analysis was performed on male mice as previously reported (Ingalls et al., 2004; Arpke et al., 2013). Briefly, mice were anesthetized with isoflurane continuously supplied by VetFlo anesthesia system (Kent Scientific) and placed on $37^{\circ} \mathrm{C}$ heating pad. Left knees were fixed by gentle pressing the knee clamps, and left feet were fixed onto the footplate that was connected to the servomotor (Aurora Scientific 1300A). The angle of the footplate was usually at $17^{\circ}$ but could be adjusted for maximal twitch force. For nerve stimulation, the sciatic nerve was exposed at thigh level and stimulated at $5 \mathrm{~mA}$ by two needle electrodes. In some experiments, muscles were directly stimulated at $2 \mathrm{~mA}$ by two needle electrodes that were inserted subcutaneously into TA muscle close to the knee. Stimulation pulse width was $0.2 \mathrm{~ms}$ for all experiments. Tetanic contractions were induced by $300 \mathrm{~ms}$ stimuli at frequencies of 50, 100, and $125 \mathrm{~Hz}$. Each tetanic contraction was followed by an interval of $\geq 2 \mathrm{~min}$. Twitch and tetanic forces were normalized by body weight.

Nerve transplant and crush surgeries. Our nerve transplant model was modified from previous reports (Payne and Brushart, 1997; Macpherson 
A

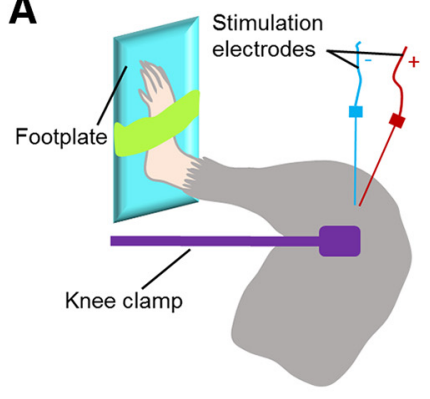

$\mathbf{E}$

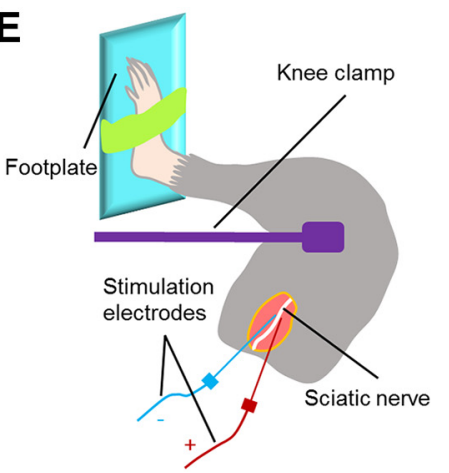

B

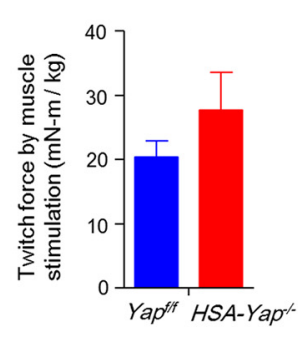

$\mathbf{F}$

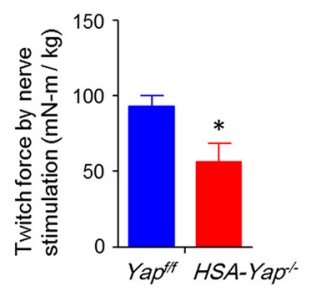

C

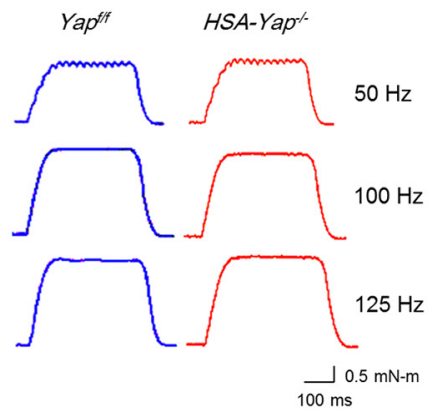

G

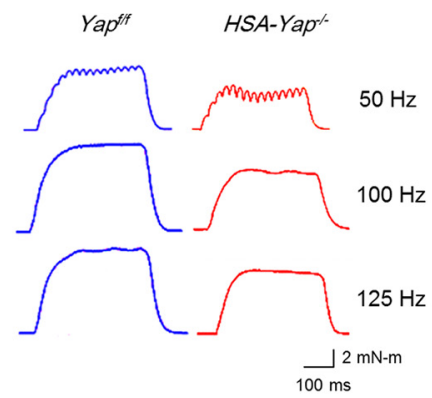

D

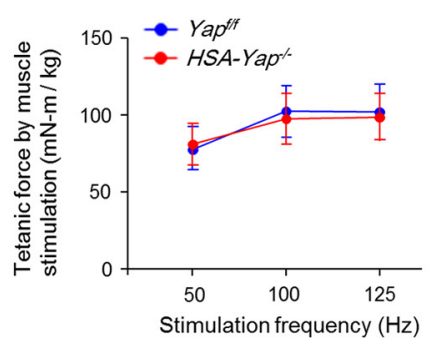

H

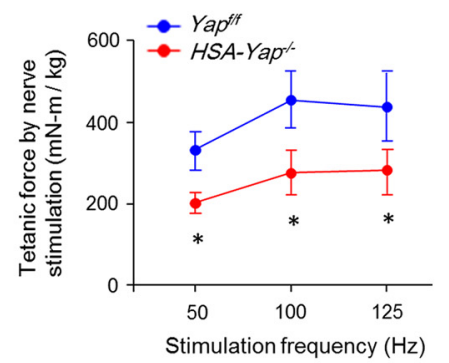

Figure 2. Reduced twitch and tetanic force by nerve stimulation in HSA-Yap ${ }^{-1-}$ mice. $\boldsymbol{A}$, Scheme of in vivo muscle twitch and tetanic force measurement by muscle stimulation. $\boldsymbol{B}$, Comparable single twitch force between control and mutant mice by muscle stimulation. $N=4$ mice per group. $\boldsymbol{C}$, Representative tetanic curves at stimulation frequency 50,100 , and $125 \mathrm{~Hz}$ by muscle stimulation. $\boldsymbol{D}$, Comparable tetanic force between control and mutant mice by muscle stimulation. $N=4$ mice per group. $\boldsymbol{E}$, Scheme of in vivo muscle twitch and tetanic force measurement by nerve stimulation. $\boldsymbol{F}$, Reduced single twitch force in $H S A-Y_{a p}{ }^{-1-}$ mice by nerve stimulation. ${ }^{*} p=0.025$ (unpaired $t$ test). $N=4$ mice per group. $\mathbf{G}$, Representative tetanic curves at stimulation frequency 50,100 , and $125 \mathrm{~Hz}$ by sciatic nerve stimulation. $\boldsymbol{H}$, Reduced tetanic force in HSA-Yap ${ }^{-/-}$mice by nerve stimulation. ${ }^{*} p<0.05$ (unpaired $t$ test). $N=4$ mice per group.

et al., 2015). Briefly, mice were anesthetized with ketamine and xylazine mixture (100 and $10 \mathrm{mg} / \mathrm{kg}$ body weight, respectively) and placed on a $37^{\circ} \mathrm{C}$ heating pad. Fur covering lower back of left calf was shaved. The region was swabbed with $5 \%$ iodine/70\% ethanol before a small incision $(\sim 1 \mathrm{~cm})$ was made on the skin. Muscles were separated by forceps to locate the tibial nerve. Both medial and lateral gastrocnemius muscles were denervated by removing a $5 \mathrm{~mm}$ segment immediately before the entrance to respective muscles. The tibial nerve was severed before it branches into lateral and medial plantar nerves, and its proximal end was transplanted and sutured to the lateral gastrocnemius ( $\sim 2 \mathrm{~mm}$ above the midline synaptic region that was identifiable by remnant nerve distal stubs as result of denervation) with 10-0 suture (Teleflex). As control, the denervated medial gastrocnemius was sutured with 10-0 suture, without being transplanted with any nerve. After surgery, skin incisions were closed by $5-0$ suture (Teleflex) and mice were kept on $37^{\circ} \mathrm{C}$ heating pad until they completely recover from anesthesia. Four weeks later, lateral and medial gastrocnemius muscles were isolated and examined for NMJ markers. In some experiments, nerves were injured by crush as described previously (Liang et al., 2012). Briefly, tibial nerves were exposed, and the branches innervating medial and lateral gastrocnemius were clamped and crushed for $30 \mathrm{~s} \times 3$ with microforceps (No. 5 Dumont; 11252-00; FST) that were precooled with liquid nitrogen $2 \mathrm{~mm}$ before entering respective muscles. Fourteen and $21 \mathrm{~d}$ after nerve crush, gastrocnemius muscles were examined.

Statistical analysis. Data were analyzed by unpaired $t$ test, one-way ANOVA, and two-way ANOVA. Unless otherwise indicated, data were shown as mean $\pm \mathrm{SD}$. Statistical difference was considered when $p<0.05$.

\section{Results}

\section{Decreased muscle strength in muscle-specific Yap} mutant mice

Yap null mice, due to abnormal neurogenesis and body axis, die at E8.5 (Morin-Kensicki et al., 2006; Nishioka et al., 2009), a time before NMJ formation, which begins at E12.5 in mice. To solve this problem, we generated Yap conditional knock-out mice by breeding HSA::Cre mice, which express Cre recombinase under the control of HSA promoter (Brennan and Hardeman, 1993; Miniou et al., 1999; Schwander et al., 2003), with $Y_{a p}{ }^{f / f}$ mice in which exons1 and 2 of Yap are flanked by loxp site (Zhang et al., 2010; Wang et al., 2014), to generate HSA::Cre;Yap ${ }^{\text {flox/flox }}$ (HSA$\left.Y_{a p}{ }^{-l-}\right)$ mice. Genotyping analysis revealed that the Yap-deleted allele was detected only in muscle, not tail DNA of $H S A-Y a p^{-1-}$ mice, indicative of muscle-specific mutation (Fig. 1A,B). Accordingly, Yap protein level was reduced only in skeletal muscles, but not in other tissues or organs, including spinal cord where motor neuron resides (Fig. 1C). To determine whether Yap mutation impairs general motor function, $H S A-Y a p^{-1-}$ mice were subjected to three muscle strength assays. First, forelimb grip strength of $H S A-Y a p^{-1-}$ mice was lower than littermate Yap ${ }^{f / f}$ control (Fig. 1D). Moreover, the time they were able to hang on a 1.5-mm-diameter wire was reduced, compared with control mice (Fig. 1E). Similarly, the latency to fall from a rotator rod was reduced (Fig. $1 F$ ). These observations demonstrate that proper motor function and muscle strength require Yap in muscle cells. However, as shown in Figure $1 G$, mRNA of key myogenic factors, including MyoD, Myf5, and myogenin, was comparable between control and mutant muscles, suggesting little effect of Yap mutation. Furthermore, there was no difference between slow and fast fiber composition in control and mutant mice (Fig. $1 \mathrm{H}, \mathrm{I}$ ). The cross-sectional area in $H S A-Y a p^{-1-}$ mice was not significantly lower than control (Fig. $1 \mathrm{H}, \mathrm{J})$, although it was reported lower in mice that were injected with Yap shRNA AAV (Watt et al., 2015). Furthermore, there was no difference in the number of muscle fibers with central nuclei between control and mutant mice (regardless of fast or slow fiber type) (Fig. $1 K, L$ ). These results suggest that HSA-Cre-mediated Yap mutation has little effect on 
A

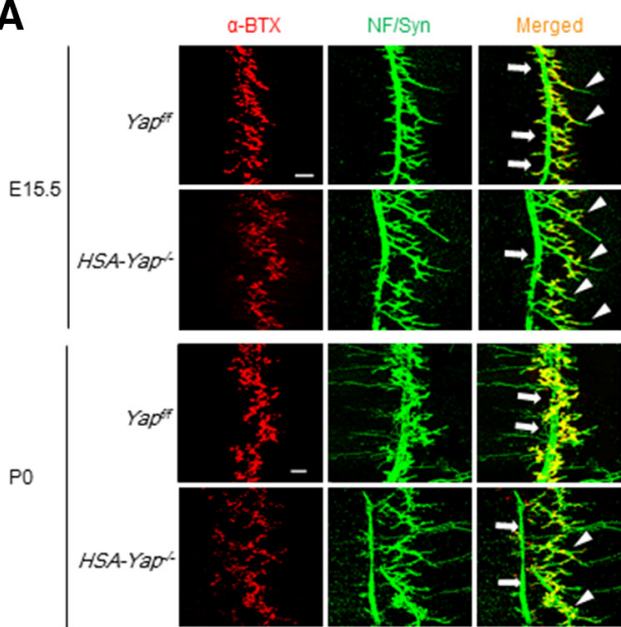

G

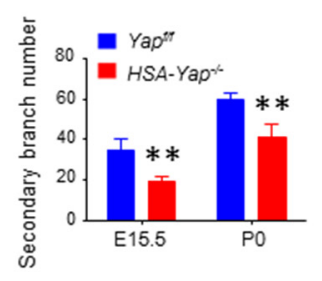

$\mathbf{H}$
B

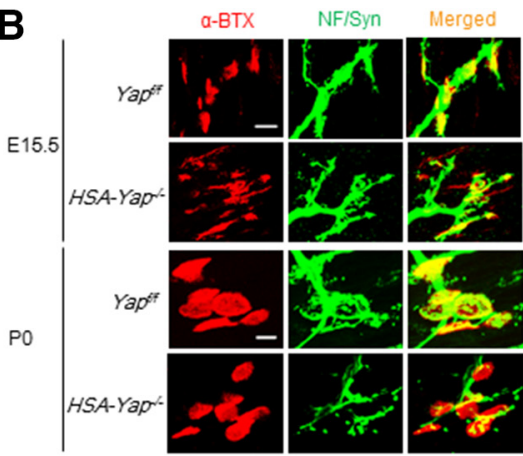

D $\tilde{E}^{\tilde{E}_{1000}}$ - Yap"

¿ 800 - HSA-Yap $^{2-}$
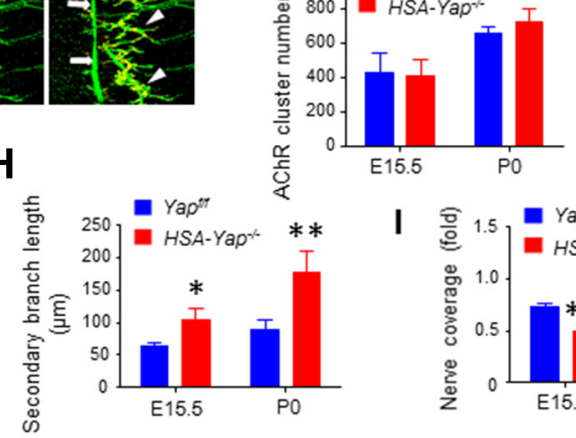

C

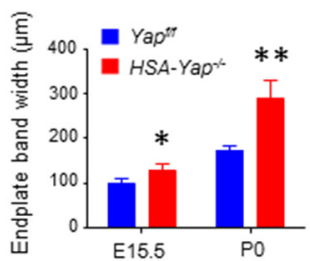

$\mathbf{F}$

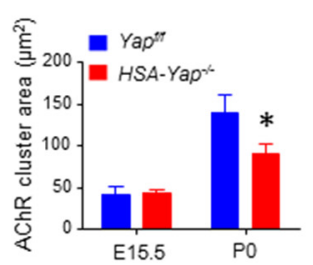

Figure 3. Postsynaptic and presynaptic deficits in HSA-Yap ${ }^{-1-}$ mice.A, Representative images of E15.5 and PO Yap ${ }^{f / f}$ and HSA-Yap ${ }^{-1-}$ diaphragm left ventral region. Muscles were stained with CF568 $\alpha$-BTX (red) and anti-NF/Syn antibodies (visualized by AlexaFluor-488 goat anti-rabbit lgG, green). Arrow indicates primary branch. Arrowhead indicates defasciculated secondary branch. Scale bar, $100 \mu \mathrm{m}$. B, Enlarged images of AChR clusters. Scale bar, $10 \mu \mathrm{m}$. C, Increased endplate band width in HSA-Yap ${ }^{-1-}$ mice. ${ }^{*} p=0.014$ for E15.5 (unpaired $t$ test). ${ }^{* *} p=0.0018$ for PO (unpaired $t$ test). $N=4$ or 5 mice per group. $D$, Comparable AChR number between Yap ${ }^{f / f}$ and $H S A-Y a p^{-1-}$ mice. $N=4$ mice per group. E, AChR cluster intensity was comparable between $Y a p^{f / f}$ and $H S A-Y a p^{-1-}$ mice. $N=4$ or 5 mice per group. $\boldsymbol{F}$, Reduced AChR area in $H S A-Y a p^{-1-}$ mice. ${ }^{*} p=0.011$ for PO (unpaired $t$ test). $N=4$ mice per group. $\boldsymbol{G}$, Reduced secondary branch number in HSA-Yap ${ }^{-1-}$ mice. ${ }^{* *} p=0.0085$ for E15.5 (unpaired $t$ test). ${ }^{* *} p=0.0014$ for PO (unpaired $t$ test). $N=4$ or 5 mice per group. $\boldsymbol{H}$, Longer secondary branch in Yap mutant mice. ${ }^{*} p=0.021$ for E15.5 (unpaired $t$ test). ${ }^{* *} p=0.0037$ for P0 (unpaired $t$ test). $N=4$ or 5 mice per group. I, Reduced nerve coverage in HSA-Yap ${ }^{-l-}$ NMJs. ${ }^{* * *} p=8.2 \mathrm{E}-5$ for E15.5 (unpaired $t$ test). ${ }^{* *} p=0.0024$ for PO (unpaired $t$ test). $N=4$ or 5 mice per group.

A
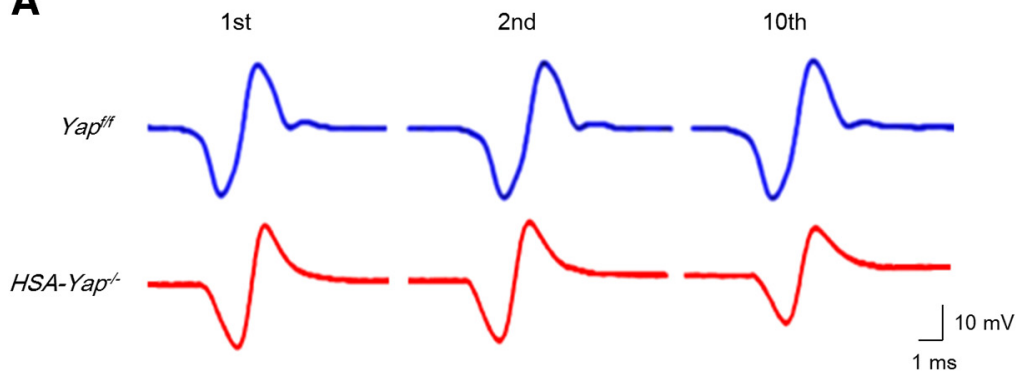

C

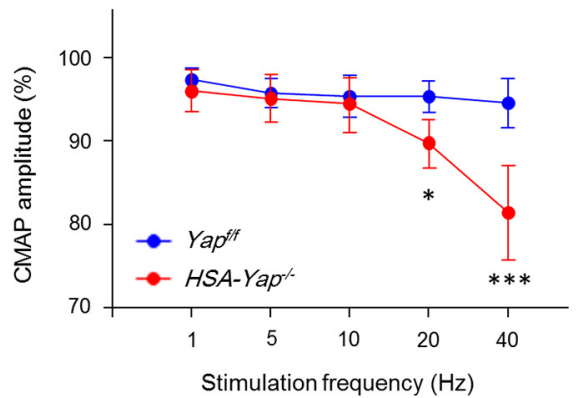

B
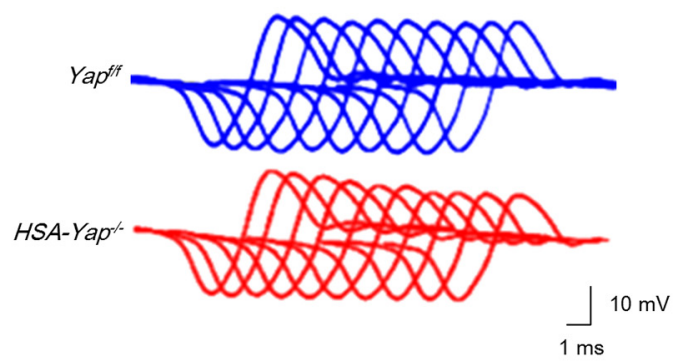

D

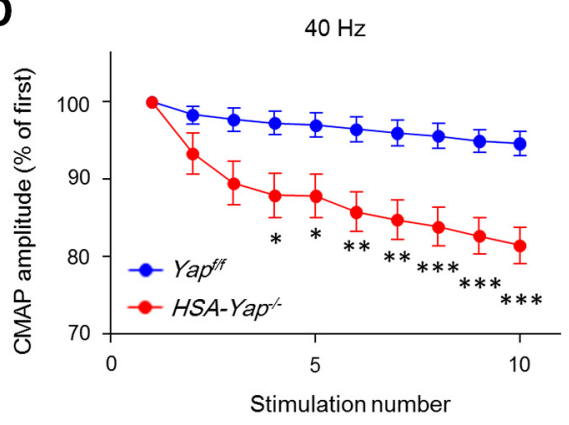

Figure 4. CMAP reduction in HSA-Yap ${ }^{-1-}$ mice. A, Representative CMAP traces of Yap ${ }^{f f f}$ and $H S A-Y a p^{-1-}$ mice in response to first, second, and 10 th stimuli at $40 \mathrm{~Hz}$. $\boldsymbol{B}$, Ten CMAP traces shown in a stacked succession for comparison. $\boldsymbol{C}, \boldsymbol{D}$, Reduced CMAP amplitudes. CMAP amplitude ratio of the 10th to the first traces at different stimulation frequency $(\boldsymbol{C})$ and reduced $C M A P$ amplitude at $40 \mathrm{~Hz}$ (D). ${ }^{*} p<0.05$ (two-way ANOVA). ${ }^{* *} p<0.01$ (two-way ANOVA). ${ }^{* * *} p<0.001$ (two-way ANOVA). $N=6$ mice per group. 
A

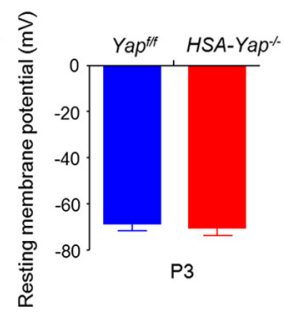

C

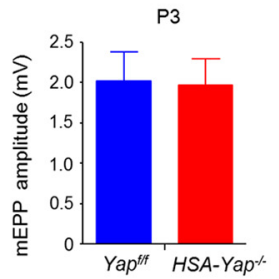

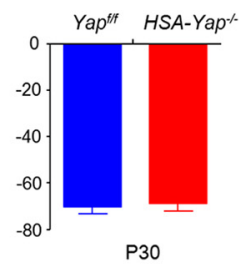

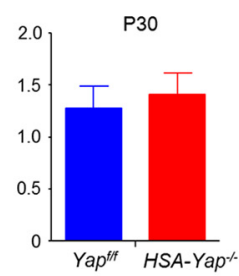

B
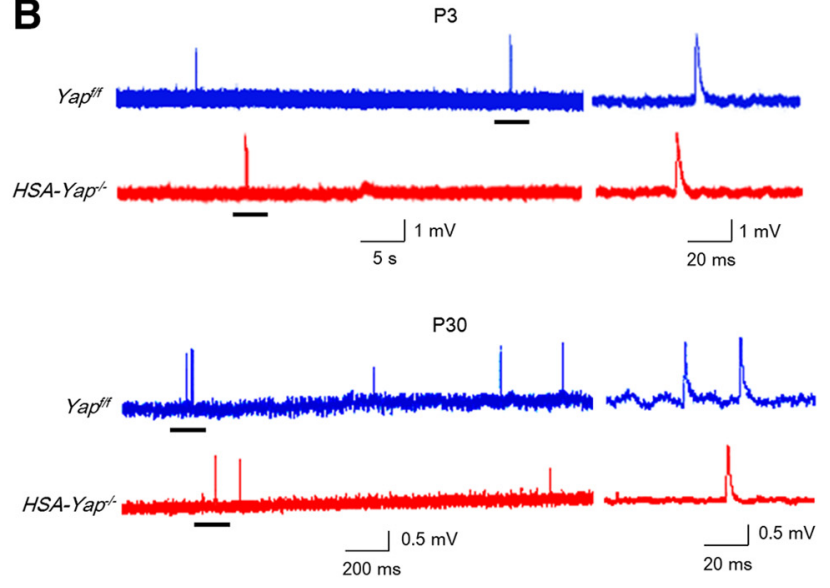

D

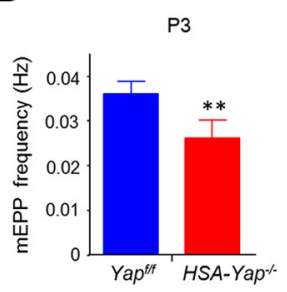

E

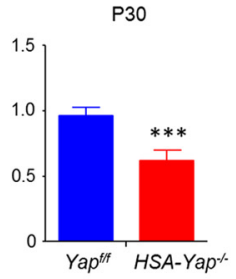

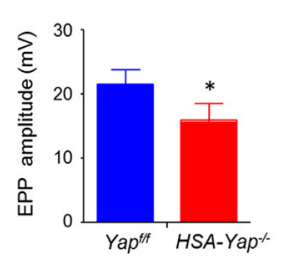

$\mathbf{F}$

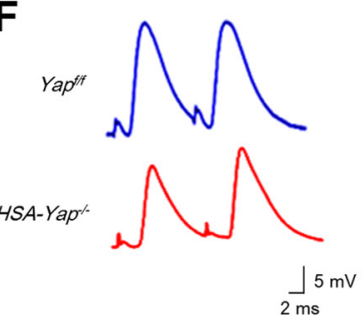

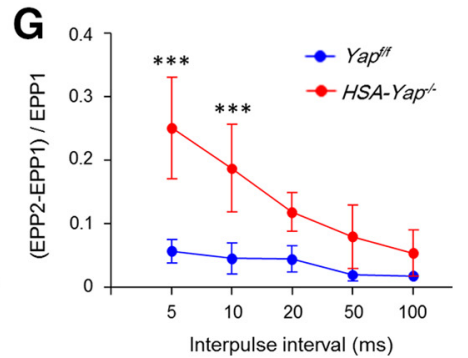

Figure 5. Impaired neuromuscular transmission in $\mathrm{HSA}-\mathrm{Yap}{ }^{-1-}$ mice. $A$, Comparable resting membrane potentials between $\mathrm{Yap} / \mathrm{f}$ and $\mathrm{HSA}-\mathrm{Yap}{ }^{-1-}$ mice at $\mathrm{P} 3$ and $\mathrm{P} 30 . \mathrm{N}=6 \mathrm{mice}$ per group. $B$, Representative mEPP traces of $\mathrm{P3}$ (top) and P30 (bottom) of $\mathrm{YaP}^{\mathrm{fff}}$ and $\mathrm{HSA}-\mathrm{Yap}^{-1-}$ mice. Underlined regions in the left were enlarged in the right. $\boldsymbol{C}, \boldsymbol{D}$, Normal $\mathrm{mEPP}$ amplitudes $(\boldsymbol{C})$ but reduced $\mathrm{mEPP}$ frequency (D) in HSA-Yap ${ }^{-1-}$ mice. ${ }^{* *} p=0.0015$ for P3 mEPP frequency (unpaired $t$ test). ${ }^{* * *} p=9.1 \mathrm{E}-6$ for P30 mEPP frequency (unpaired $t$ test). $N=6$ mice per group. $E$, Reduced EPP amplitudes in $H_{S A-Y a p^{-I-}}$ mice. ${ }^{*} p=0.016$ (unpaired $t$ test). $N=6$ mice per group. $\boldsymbol{F}$, Representative paired-pulse traces at $10 \mathrm{~ms}$ of stimulation interval. $\boldsymbol{G}$, Increased paired-pulse facilitation in $H S A-Y_{a p}{ }^{-1-}$ mice. ${ }^{* *} p<0.001$ (two-way ANOVA). $N=4$ mice per group.

muscle differentiation in vivo, perhaps due to the fact that Cre expression controlled by $\alpha$-skeletal actin-promoter occurs after myoblasts fuse to myotubes (van der Ven et al., 1992; Brennan and Hardeman, 1993).

To determine pathological mechanisms by which Yap mutation reduces muscle strength, we measured muscle contractions by stimulating nerve and muscle, respectively. Nerve stimulation requires proper neuromuscular transmission to induce muscle contraction, whereas direct muscle stimulation does not. As shown in Figure $2 A-D$, muscle direct stimulation elicited comparable twitch and tetanic contractions between control and $H S A-Y a p^{-1-}$ mice, suggesting little effect of Yap mutation on muscle contractile machinery. In contrast, nerve stimulationinduced twitch and tetanic contractions were reduced in HSA$\mathrm{Yap}^{-1-}$ muscles (Fig. $2 \mathrm{~F}-H$ ). These results are in agreement with morphological studies (Fig. $1 H-L$ ) and suggest that Yap muscle mutation may not alter muscle contraction. Rather, muscle weakness in HSA-Yap ${ }^{-1-}$ mice may be due to problems of neuromuscular transmission.

\section{Presynaptic and postsynaptic deficits in muscle specific Yap mutant mice}

To investigate how Yap mutation alters neuromuscular transmission, we examined diaphragm muscles at E15.5, when NMJs initially form, and at P0 when NMJs begin to mature (Wu et al., 2010). Muscles were stained with CF568-conjugated $\alpha$-BTX to visualize $A C h R$ and antibodies against neurofilament (NF) and synapsin (Syn) to visualize axons and terminals. AChR clusters in control mice at these ages were opaque, not perforated, and localized in the middle regions of muscle fibers (Fig. 3A,B) (Li et al., 2008; Wu et al., 2012b). However, in HSA-Yap ${ }^{-1-}$ mice, the clusters were distributed in a wider region at E15 and P0 (Fig. $3 A, C)$. The total number of AChR clusters and the average intensity of each endplate were not changed at both ages (Fig. $3 D, E)$. There was no difference between E15.5 control and mutant mice in area or size of clusters $(42.8 \pm 9$ and $43.5 \pm 4$ for control and mutant, respectively; $p=0.89, N=4$ mice per group). In contrast, P0 mutant mice displayed smaller AChR clusters (Fig. $3 B, F)(140 \pm 21$ and $90 \pm 12$ for control and mutant, respectively; $p=0.011, N=4$ mice per group). This could suggest morbid expansion of AChR size in Yap mutant mice.

Intriguingly, $H S A-Y a p^{-/-}$mice displayed presynaptic morphological deficits, although Yap was specifically mutated in muscle cells. In control mice, the primary branch of phrenic nerve traversed through the center of muscle fibers of the hemidiaphragm; secondary branches were short and distributed on both sides of the primary branches (Fig. $3 A$ ). In contrast, in HSA$\mathrm{Yap}^{-1-}$ mice, the primary branch at both E15.5 and P0 was located toward the central cavity (which was located on the left). Moreover, the number of secondary branches was reduced by $43.1 \%$ at E15.5 and by $31.2 \%$ at P0 (34 \pm 6 in control to $19 \pm 2$ in E15.5 HSA-Yap ${ }^{-1-}$ mice; $p=0.0086 ; 60 \pm 4$ in control to $41 \pm 6$ in P0 HSA-Yap ${ }^{-1-}$ mice; $p=0.0014, N=4$ or 5 mice per group). The length of secondary branches was increased by $67 \%$ at E15.5 and $101 \%$ at $\mathrm{P} 0(62 \pm 7 \mu \mathrm{m}$ in control and $104 \pm 20 \mu \mathrm{m}$ in E15.5 mutant mice, $p=0.021 ; 88 \pm 14 \mu \mathrm{m}$ in control to $177 \pm 37 \mu \mathrm{m}$ in P0 mutant mice, $p=0.0037, N=4$ or 5 mice per group) (Fig. $3 G, H)$. In control mice, AChR clusters showed almost complete registry with markers of nerve terminals. However, some areas 

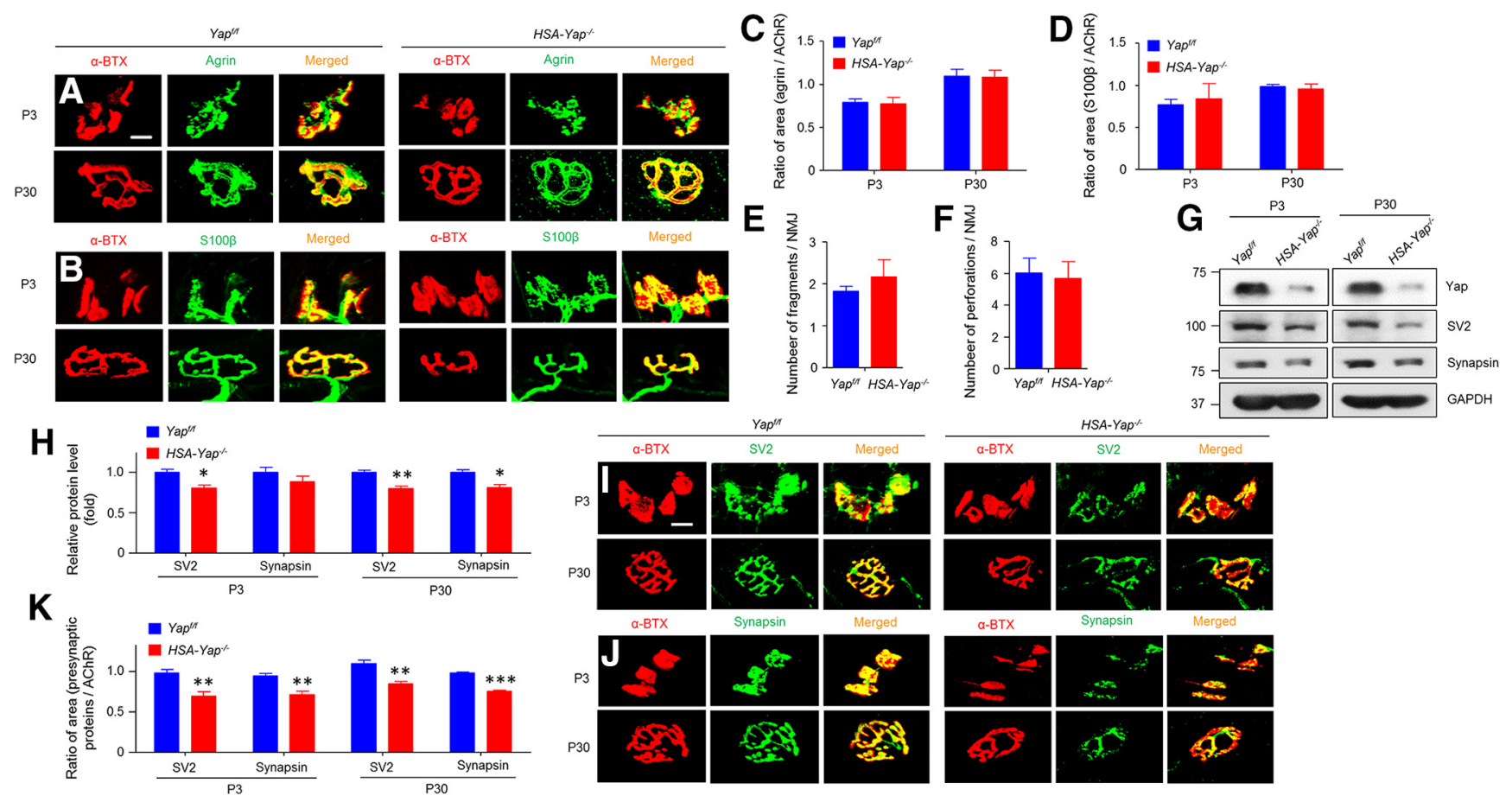

Figure 6. Reduced nerve terminal proteins in $H S A-Y a p^{-1-}$ mice. $\boldsymbol{A}, \boldsymbol{B}$, No difference of agrin $(\boldsymbol{A})$ and $S 100 \beta(\boldsymbol{B})$ staining in gastrocnemius between $\operatorname{Yap}^{\mathrm{fff}}$ and $H S A-Y a p^{-1-}$ mice. Muscles were stained whole-mount with respective antibodies. Scale bar, $10 \mu \mathrm{m} . \boldsymbol{C}, \boldsymbol{D}, \alpha$-BTX area covered by agrin $(\boldsymbol{C})$ and $S 100 \beta(\boldsymbol{D}) . N=5$ or 6 mice per group. $\boldsymbol{E}, \boldsymbol{F}$, Quantification of pretzel-like structures at P30. Comparable AChR fragment number $(\boldsymbol{E})$ and perforation $(\boldsymbol{F})$ between $\mathrm{Yap}^{f / f}$ and $H S A-Y a p^{-/-}$mice. $N=5$ mice per group. $\boldsymbol{G}$, Reduced SV2 and synapsin protein in synaptic region of gastrocnemius. $\boldsymbol{H}$, Quantification of data in $\boldsymbol{G} .{ }^{*} p=0.019$ for P3 SV2 (unpaired $t$ test). ${ }^{* *} p=0.0059$ for P30 SV2 (unpaired $t$ test). ${ }^{*} p=0.017$ for P30 synapsin (unpaired $t$ test). $N=3$ mice per group. $\boldsymbol{I}, \boldsymbol{J}$, Reduced SV2 $(\boldsymbol{I})$ and synapsin $(\boldsymbol{J})$ staining at mutant NMJ. Gastrocnemius was stained whole-mount with respective antibodies. Scale bar, $10 \mu \mathrm{m} . \boldsymbol{K}$, Reduced $\alpha$-BTX area covered by SV2 and synapsin. ${ }^{* *} p=0.0013$ for P3 SV2 (unpaired $t$ test). ${ }^{* *} p=0.0014$ for P3 synapsin (unpaired $t$ test). ${ }^{* *} p=0.0021$ for P30 SV2 coverage (unpaired $t$ test). ${ }^{* * *} p=2.4 \mathrm{E}-7$ for P30 synapsin coverage (unpaired $t$ test). $N=5$ or 6 mice per group.

labeled by AChR were not covered by presynaptic terminals in mutant mice at both ages (Fig. $3 B, I$ ). These results indicate that Yap in skeletal muscle is required for NMJ formation and that changes in presynaptic innervation in Yap mutant muscle may not be due to a secondary effect of delayed electrical activity.

Impaired neuromuscular transmission in $\mathrm{HSA}-\mathrm{Yap}^{-/-}$mice Next, we recorded CMAPs, action potentials that are triggered by 10 consecutive nerve stimuli (Shen et al., 2013; Barik et al., 2014b). In control mice at age of P30, CMAP amplitudes between the first and 10th stimuli were similar, regardless of the frequency of the stimuli (even at $40 \mathrm{~Hz}$ ) (Fig. $4 A-C$ ). However, in HSA$\mathrm{Yap}^{-1-}$ mice, CMAP amplitudes at the 10th stimuli were significantly smaller, compared with the first, beginning at $20 \mathrm{~Hz}$ (Fig. $4 A-D)$. At $40 \mathrm{~Hz}, \mathrm{CMAP}$ reduction was detectable at fourth stimulation (Fig. 4D). Moreover, CMAP reduction was frequencydependent (Fig. 4C), which indicated a progressive failure of neuromuscular transmission following repetitive stimulations.

To characterize the cellular mechanism of this neuromuscular transmission deficit, we measured mEPPs, local depolarizations around endplates in response to spontaneous ACh release (Liu et al., 2010; Chen et al., 2011; Nelson et al., 2013). Resting membrane potentials were similar between control and HSA-Yap ${ }^{-1-}$ mice at age of $\mathrm{P} 3$ and $\mathrm{P} 30$, suggesting that Yap mutation had little effect on muscle electric property (Fig. $5 A$ ). mEPP amplitudes in $H S A-Y a p^{-1-}$ mice were comparable with those in control mice at age of P30, suggesting that postsynaptic AChR density at the NMJ was not changed by Yap muscle mutation (Fig. $5 B, C$ ), in agreement with no change in AChR intensity in morphological study (Fig. 3E). In contrast, mEPP frequency was decreased from
$0.96 \pm 0.06 \mathrm{~Hz}$ in control mice to $0.62 \pm 0.08 \mathrm{~Hz}$ in $\mathrm{HSA}-\mathrm{Yap}^{-1-}$ mice at age of $\mathrm{P} 30$ ( $p=9.1 \mathrm{E}-6, N=6$ mice per group) (Fig. $5 B, D)$. These results suggest possible impairment in ACh release in HSA-Yap ${ }^{-1-}$ mice. To determine whether this was a developmental defect or a phenotype due to adaptation, we characterized $\mathrm{mEPP}$ at age of $\mathrm{P} 3$. As shown in Figure $5 B, D$, mEPP frequency was reduced from $0.036 \pm 0.004 \mathrm{~Hz}$ in control mice to $0.026 \pm$ $0.004 \mathrm{~Hz}$ in $H S A-Y a p^{-1-}$ mice $(p=0.0015, N=6$ mice per group), whereas no change in $\mathrm{mEPP}$ amplitudes was observed (Fig. 5C). These results suggest abnormal presynaptic differentiation in the absence of muscle Yap protein.

Finally, we measured EPPs, local electrical responses in response to nerve stimulation. Because mEPP frequency reduction was more dramatic at P30 than P3, we focused on EPPs of P30 mice. As shown in Figure 5E, EPP amplitude was reduced in $H S A-Y a p^{-1-}$ mice $(21.5 \pm 2.8$ vs $15.9 \pm 3.7 \mathrm{mV}, p=0.016, N=$ 6 mice per group), indicating compromised evoked vesicle release. To further test whether $\mathrm{mEPP}$ frequency reduction was due to change in vesicle release probability, we examined EPPs in response to two consecutive stimuli. In control mice, EPP caused by the second pulse is higher, in a phenomenon called pairedpulse facilitation (PPF), because of increased residual calcium concentration at the presynaptic terminal due to the first pulse. At 5 and $10 \mathrm{~ms}$ intervals, PPF was higher at NMJs from HSA$\mathrm{Yap}^{-1-}$ mice than control mice, suggesting reduced release probability of synaptic vesicles and/or calcium buffering (through endoplasmic reticulum or mitochondria) in the presynaptic terminal of HSA-Yap ${ }^{-1-}$ mice (Fig. 5G). These electrophysiological results were indicative of compromised probability of calciumdependent vesicle release. Together, our findings are suggestive of 
A

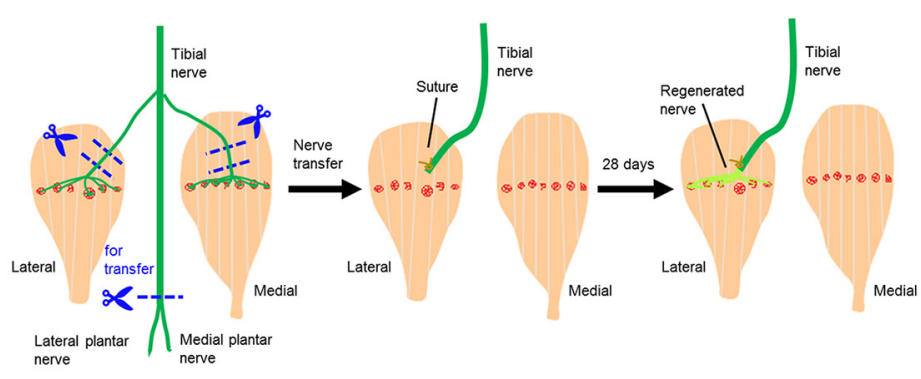

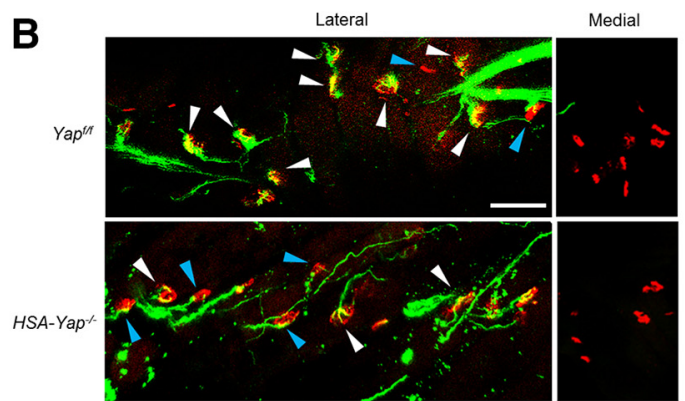

C

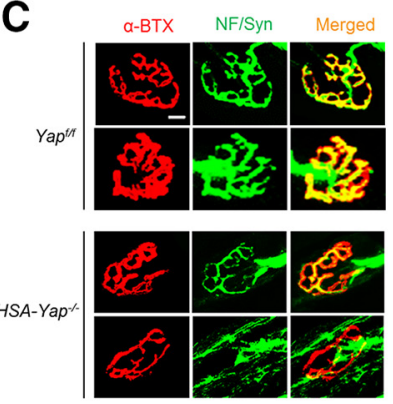

D

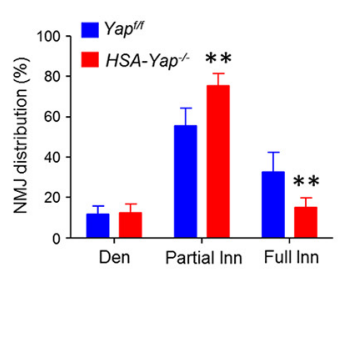

E

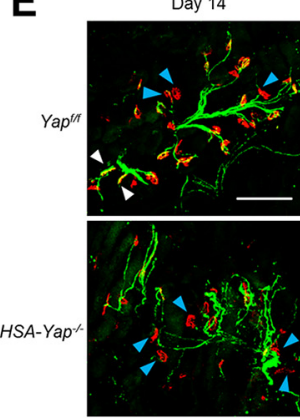

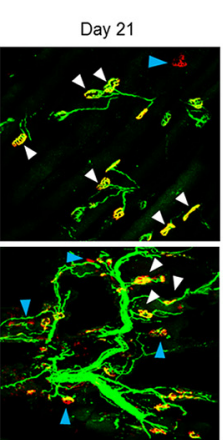

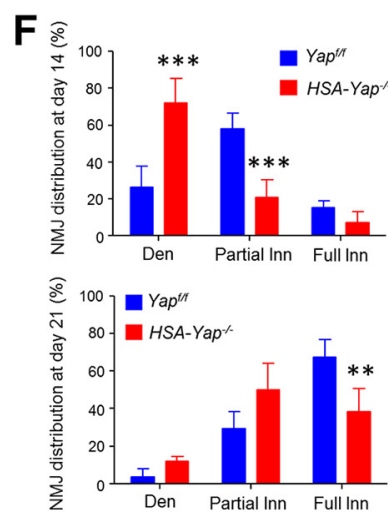

Figure 7. Compromised NMJ regeneration in HSA-Yap ${ }^{-1-}$ mice. A, Schematic diagram of tibial nerve transplant surgery. Both medial and lateral gastrocnemius muscles were denervated by removing a $5 \mathrm{~mm}$ segment immediately before the entrance to respective muscles. The tibial nerve was severed before it branches into lateral and medial plantar nerves, and its proximal end was transplanted and sutured $\sim 2 \mathrm{~mm}$ above the midline synaptic region of the lateral gastrocnemius. As control, the denervated medial gastrocnemius was not transplanted with a nerve (see Materials and Methods). $\boldsymbol{B}$, Representative images of NMJ regeneration in lateral (left panel), but not medial (right panels) gastrocnemius, 4 weeks after nerve transplant surgery. White arrowheads indicate fully reinnervated AChR clusters. Blue arrowheads indicate partially reinnervated or denervated AChR clusters. Scale bar, $100 \mu \mathrm{m}$. C, Enlarged images of newly generated NMJs. Scale bar, $10 \mu \mathrm{m}$. D, Decreased fully reinnervated and increased partially reinnervated AChR clusters in HSA-Yap ${ }^{-1-}$ mice. Den, Denervated AChR clusters; Partial Inn, partially reinnervated AChR clusters; Full Inn, fully reinnervated AChR clusters. ${ }^{* *} p<0.01$ (two-way ANOVA). $N=4$ mice per group. $E$, Representative images of NMJ regeneration in gastrocnemius 14 and $21 \mathrm{~d}$ after nerve crush. White arrowheads indicate fully reinnervated AChR clusters. Blue arrowheads indicate partially reinnervated or denervated AChR clusters. Scale bar, $200 \mu \mathrm{m}$. $\boldsymbol{F}$, Reduced fully reinnervated and increased denervated AChR clusters in HSA-Yap ${ }^{-1-}$ mice after nerve crush. ${ }^{* * *} p<0.001$ for denervated and partially reinnervated AChR clusters $14 \mathrm{~d}$ after crush (two-way ANOVA). ${ }^{* *} p<0.01$ for fully innervated AChR clusters $21 \mathrm{~d}$ after crush (two-way ANOVA). $N=4$ mice per group.

presynaptic deficits in neuromuscular transmission in HSAYap ${ }^{-1-}$ mice.

\section{Reduced nerve terminal proteins in $\mathrm{HSA}-\mathrm{Yap}^{-1-}$ mice}

To investigate the underlying mechanisms of muscle Yap mutation, we further characterized NMJs in mutant mice. Staining with antibodies against agrin, a proteoglycan released by nerve terminals to induce $\mathrm{AChR}$ clustering, and $\mathrm{S} 100 \beta$, a marker of differentiated Schwann cells, were comparable between HSA$\mathrm{Yap}^{-1-}$ and control mice at both P3 and P30 (Fig. 6A-D), indicating normal agrin release and Schwann cells. Moreover, there was no difference in the number of AChR cluster fragments or perforated clusters between control and HSA-Yap ${ }^{-1-}$ mice (Fig. $6 E, F)$, again suggesting normal postsynaptic differentiation. However, the area of endplates covered by nerve terminals was reduced as shown previously (Fig. $3 B, I$ ), suggesting an impaired presynaptic differentiation. To test this hypothesis further, we isolated muscle central regions (where nerve terminals are enriched) from P3 and P30 mice and examined by Western blot SV2 and synapsin, two presynaptic vesicle markers for differentiated nerve terminal. Intriguingly, both were reduced at the protein level (Fig. 6G,H). In morphology studies, the presynaptic markers colocalized well with postsynaptic AChR in control mice; however, the AChR area covered by SV2 or synapsin was reduced (by $28.8 \%$ and $24.4 \%$ at $\mathrm{P} 3$ and $22.6 \%$ and $22.7 \%$ in P30, respectively) in the mutant group (Fig. 6I-K). These results were in agreement with electrophysiological studies and indicated that presynaptic structure and function were deficient in HSA$\mathrm{Yap}^{-1-}$ mice.

\section{Muscle Yap regulation of NMJ regeneration}

NMJ regenerates after nerve injury (Mitsumoto and Bradley, 1982; Payne and Brushart, 1997; Macpherson et al., 2015). This event also requires intimate interaction between motor nerve terminals and endplates on skeletal muscle. Having demonstrated that muscle Yap is required for NMJ presynaptic differentiation, we next examined whether muscle Yap is also required for NMJ regeneration. To this end, we established a nerve transplant model (Payne and Brushart, 1997; Macpherson et al., 2015). In mouse, the tibial nerve innervates both medial and lateral gastrocnemius and other muscles in the hindlimb (Fig. 7A). We denervated medial and lateral gastrocnemius by removing a 5 $\mathrm{mm}$ segment immediately before the branch enters the respective muscle. The main tibial nerve branch was severed, and the proximal end was transplanted and sutured $\sim 2 \mathrm{~mm}$ above the middle of lateral gastrocnemius, whereas the medial gastrocnemius was left uninnervated (as control) (Fig. 7A). Four weeks after surgery, both lateral and medial gastrocnemius were isolated and stained for AChR and presynaptic markers. Four weeks after surgery, nerve terminal markers were detectable in lateral, but not medial, gastrocnemius, although AChR clusters were visible in both muscles (Fig. $7 B$ ). These results indicate NMJ regenerations between newly arrived nerve terminals and previous AChR clusters. We compared regenerated NMJs in lateral gastrocnemius of control 

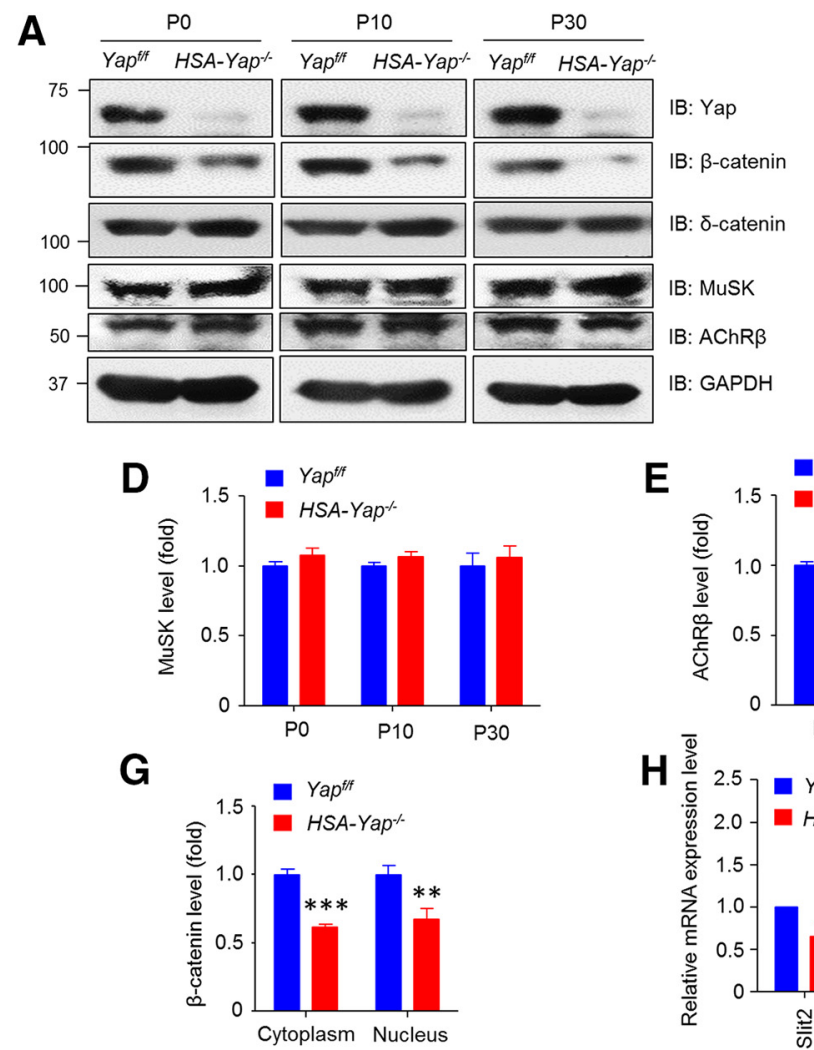
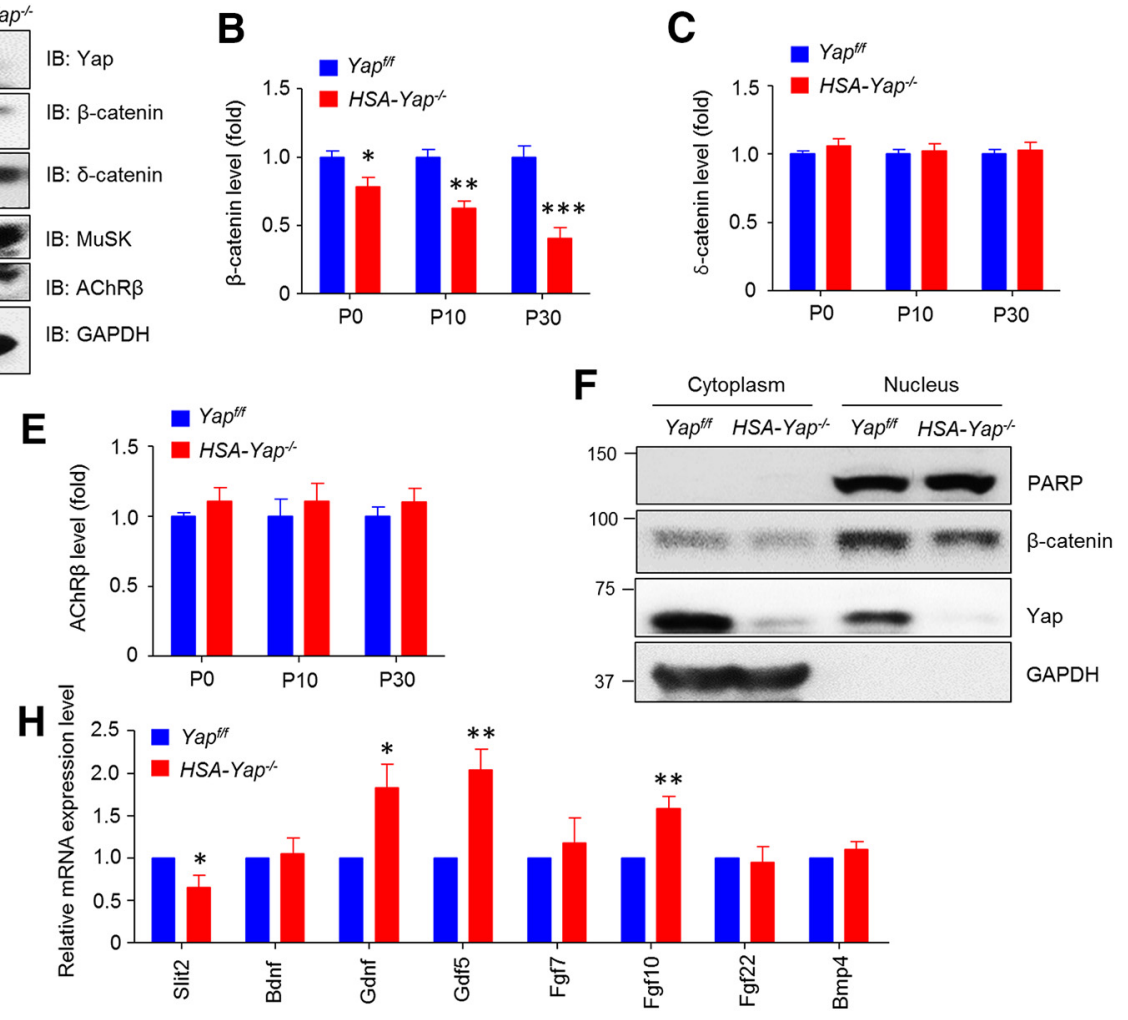

Figure 8. Reduced $\beta$-catenin and Slit2 in HSA-Yap ${ }^{-1-}$ mice. $\boldsymbol{A}, \beta$-Catenin was reduced in HSA-Yap ${ }^{-/-}$gastrocnemius. $\boldsymbol{B}-\boldsymbol{E}$, Quantification of $\beta$-catenin ( $\left.\boldsymbol{B}\right)$, $\delta$-catenin ( $\boldsymbol{C}$, MuSK (D), and AChR $\beta$-subunit $(\boldsymbol{E})$ data in $\boldsymbol{A} . \boldsymbol{B},{ }^{*} p=0.016$ for P0 (unpaired $t$ test). ${ }^{* *} p=0.0011$ for P10 (unpaired $t$ test). ${ }^{* * *} p=0.00077$ for P30 (unpaired $t$ test). $N=3$ mice per group. $\boldsymbol{F}, \beta$-Catenin was reduced at both nuclear and cytoplasmic fraction in P30 HSA-Yap ${ }^{-1-}$ gastrocnemius. G, Quantification of data in $\boldsymbol{F} .{ }^{* * *} p=0.00052$ for cytoplasmic fraction (unpaired $t$ test). ${ }^{* *} p=0.0055$ for nuclear fraction (unpaired $t$ test). $N=3$ mice per group. $\boldsymbol{H}$, mRNA levels of factors implicated in NMJ formation. ${ }^{*} p=0.029$ for Slit2 (unpaired $t$ test). ${ }^{*} p=0.031$ for Gdnf (unpaired $t$ test). ${ }^{* *} p=0.0067$ for Gdf5 (unpaired $t$ test). ${ }^{* *} p=0.0045$ for Fgf10 (unpaired $t$ test). $N=3$ or 4 mice per group.

and Yap mutant mice. Almost all AChR clusters in control mice were stained positive with nerve terminals; many displayed apparent overlap of AChR and NF/Syn (Fig. $7 B, C$ ). However, in HSA-Yap ${ }^{-1-}$ mice, many AChR clusters in lateral gastrocnemius remained partially innervated. We categorized reinnervated AChR clusters based on the extent of nerve-endplate overlap as described previously (Macpherson et al., 2015): fully reinnervated AChR clusters ( $80 \%-100 \%$ overlap), partially reinnervated AChR clusters (10\%-80\% overlap), and denervated AChR clusters $(<10 \%$ overlap). Compared with control mice, fully reinnervated clusters decreased by $17.8 \%$ in $H S A-Y a p^{-1-}$ mice. Concomitantly, partially reinnervated clusters increased by $19.8 \%$ in $H S A-Y_{a p}{ }^{-1-}$ mice, compared with control littermates $(p<0.01, N=4$ mice per group) (Fig. $7 D)$. These results indicate that muscle Yap may be necessary for NMJ regeneration. To further test this hypothesis, we examined NMJ regeneration in a different model where nerves were injured by crushing with liquid nitrogen-cooled forceps (Liang et al., 2012). As shown in Figure $7 E, F$, at $14 \mathrm{~d}$ after crush, more AChR clusters remained denervated in HSA-Yap ${ }^{-1-}$ mice, compared with control mice. At this time, fully reinnervated AChR clusters were sparse in both control and mutant mice. At $21 \mathrm{~d}$ after crush, many clusters were reinnervated in control mice, but not in $H S A-Y a p^{-1-}$ mice. These observations corroborate a role of muscle Yap for proper endplate reinnervation after nerve injury.

\section{Reduced $\boldsymbol{\beta}$-catenin and Slit2 in $\mathrm{HSA}-\mathrm{Yap}^{-1-}$ mice}

Next, we explored molecular mechanisms by which muscle Yap regulates presynaptic differentiation. Major NMJ deficits of $H S A-$
$Y_{a p}{ }^{-1-}$ mice include mislocated primary branch of phrenic nerve, longer secondary branch, wider endplate region, reduced nerve terminal, and compromised ACh release (Figs. 3, 5). These phenotypes resemble those in mice lacking $\beta$-catenin in the muscle (Li et al., 2008; Liu et al., 2012; Wu et al., 2012a. 2015). The phenotypic similarity suggests $\beta$-catenin as a potential target of Yap mutation. To test this hypothesis, we measured $\beta$-catenin in muscles by Western blot analysis. $\beta$-Catenin was reduced by $22 \%, 38 \%$, and $60 \%$ in muscles of $\mathrm{HSA}-\mathrm{Yap}^{-1-}$ mice at ages of $\mathrm{P} 0, \mathrm{P} 10$, and $\mathrm{P} 30$, respectively (Fig. $8 A, B$ ), compared with control mice. This reduction appeared to be specific because levels of $\delta$-catenin, MuSK, and AChR $\beta$-subunit were similar between control and Yap mutant mice (Fig. $8 A, C, D, E$ ).

Muscle $\beta$-catenin is thought to regulate presynaptic differentiation by controlling expression of releasable factors, such as Slit2 (Wu et al., 2015). We then determined whether nuclear $\beta$-catenin was altered in HSA-Yap ${ }^{-1-}$ muscles. Indeed, $\beta$-catenin was reduced by $32 \%$ in the nuclear fraction of mutant muscles, compared with control (Fig. 8F,G). As internal control, PARP (a nuclear protein involved in DNA repair and programmed cell death) was similar in muscle nuclear fractions between control and Yap mutant mice, indicating the specificity of $\beta$-catenin reduction. Next, we used RTPCR to screen for muscle-derived factors that were previously identified. BDNF was shown to ameliorate motor neuron survival in vitro and in vivo (Oppenheim et al., 1993; Santos et al., 2016), but its mRNA level was similar between control and mutant muscles. Increased Gdnf level caused poly-innervation (Oppenheim et al., 1995; Keller-Peck et al., 2001). However, Gdnf and Gdf5 were increased in HSA-Yap ${ }^{-1-}$ muscles $(1.83 \pm 0.43$ and $2.04 \pm 0.31$ above control, 

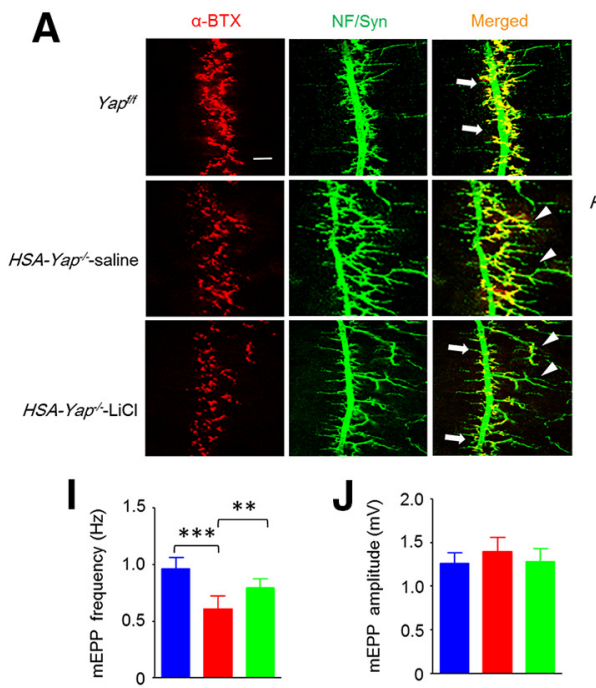

K

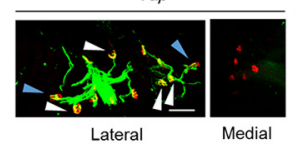

B

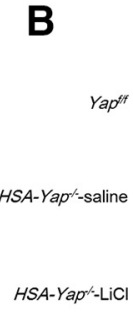

$\mathbf{F}$

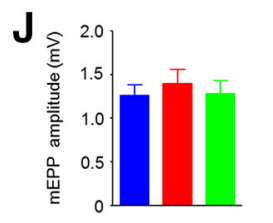

HSA-Yap ${ }^{*}$-saline

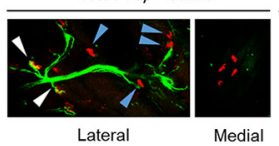

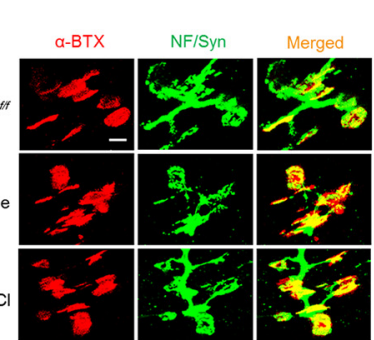

C

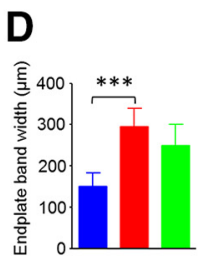

$\mathbf{E}$

G
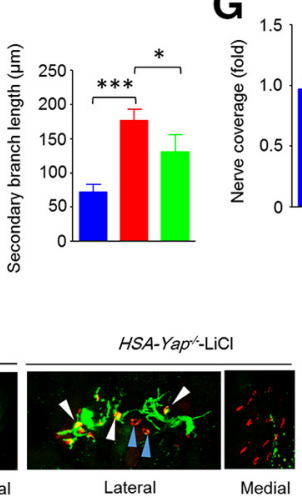
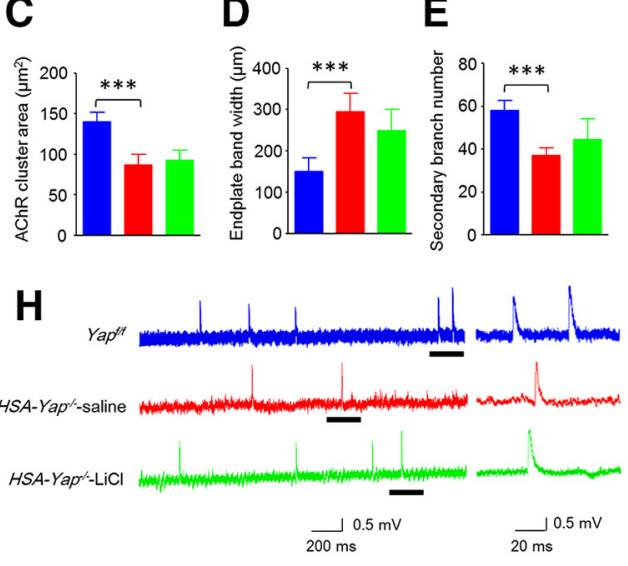

$20 \mathrm{~ms}$

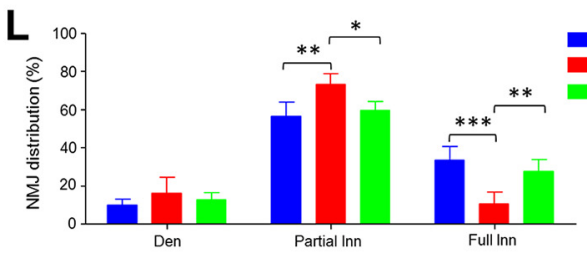

Figure 9. Partial rescue of NMJ formation and regeneration deficits by LiCl treatment. $A$, Representative images of diaphragm left ventral region of different mice. Muscles were stained with CF568 $\alpha$-BTX (red) and anti-NF/Syn antibodies (visualized by AlexaFluor-488 goat anti-rabbit lgG, green). Arrow indicates primary branch. Arrowhead indicates defasciculated secondary branch. Scale bar, $100 \mu \mathrm{m}$. $\boldsymbol{B}$, Enlarged images of AChR clusters and nerve terminals. Scale bar, $10 \mu \mathrm{m}$. $\boldsymbol{C}, \boldsymbol{D}$, No effect of LiCl on reduced AChR area $(\boldsymbol{C})$ or increased endplate band width $(\boldsymbol{D}) . \boldsymbol{E}, \boldsymbol{F}$, No effect on secondary branch number was observed for LiCl, but secondary branch length was reduced in LiCl-treated HSA-Yap ${ }^{-1-}$ mice compared with saline-treated mutant mice. ${ }^{* * *} p=3.9 \mathrm{E}-5$ for group Yap ${ }^{f / f}$ versus HSA-Yap ${ }^{-1-}$-saline (one-way ANOVA). ${ }^{*} p=0.028$ for group HSA-Yap ${ }^{-1-}$-saline versus HSA-Yap ${ }^{-1-}$-LiCl (one-way ANOVA). $N=6$ mice per group. $\mathbf{G}$, Nerve coverage was increased in LiCl-treated mutant mice compared with saline-treated mutant. ${ }^{* * *} p=0.00019$ for group Yap ${ }^{f / f}$ versus $H S A-Y a p^{-1-}$-saline (one-way ANOVA). ${ }^{* *} p=0.0023$ for group HSA-Yap ${ }^{-1-}$-saline versus HSA-Yap ${ }^{-1-}$-LiCl (one-way ANOVA). $N=6$ mice per group. $\boldsymbol{H}-J$, $\mathrm{mEPP}$ frequency in $H S A-Y_{a p}{ }^{-l-}$ mice was increased after LiCl treatment. $\boldsymbol{H}$, Representative mEPP traces. Underlined regions in the left were enlarged in the right. $\boldsymbol{I}$, Reduced mEPP frequency was rescued by LiCl treatment. ${ }^{* * *} p=0.00012$ for group Yap ${ }^{f / f}$ versus HSA-Yap ${ }^{-1-}$-saline (one-way ANOVA). ${ }^{* *} p=0.0058$ for group HSA-Yap ${ }^{-1-}$-saline versus HSA-Yap ${ }^{-I-}$-LiCl (one-way ANOVA). $N=6$ mice per group. $J$, mEPP amplitude was comparable among all groups. $K$, $L$, More fully reinnervated AChR clusters in LiCl-treated HSA-Yap ${ }^{-/-}$mice compared with saline-treated mutant mice. $\boldsymbol{K}$, Representative images of regenerated NMJs. White arrowhead indicates fully reinnervated AChR clusters. Blue arrowhead indicates partially reinnervated or denervated AChR clusters. Scale bar, $100 \mu \mathrm{m}$. L, More fully innervated AChR clusters in LiCl-treated mutant mice. ${ }^{*} p<0.05$ (two-way ANOVA). ${ }^{* *} p<0.01$ (two-way ANOVA). ${ }^{* * *} p<$ 0.001 (two-way ANOVA). $N=4$ mice per group.

$p=0.031$ and $p=0.0067$, respectively; $N=4$ mice of each genotype) (Fig. $8 H$ ). Muscle Yap mutation appeared to increase levels of Fgf10 $(1.58 \pm 0.15$-fold above control, $p=0.004, N=4$ mice of each genotype) but had no effect on levels of Fgf7, Fgf22, or Bmp4. In our screen, the only factor whose expression was reduced in mutant muscles was Slit2, at $0.65 \pm 0.17$ of control ( $p=0.029, N=4$ mice of each genotype). These observations suggest the possible involvement of $\beta$-catenin and Slit2 in Yap-dependent retrograde signaling.

\section{Partial rescue of NMJ formation and regeneration deficits by lithium chloride $(\mathrm{LiCl})$ treatment}

$\mathrm{LiCl}$ is a well-characterized inhibitor of glycogen synthase kinase $3 \beta$. Inhibition of glycogen synthase kinase $3 \beta$ activates $\beta$-catenin signaling. $\mathrm{LiCl}$ has been used recently to determine Wnt canonical pathway in NMJ formation (Messéant et al., 2015). We used this method to determine whether $\beta$-catenin activation mitigates NMJ formation deficits in HSA-Yap ${ }^{-1-}$ mice. We treated pregnant mice daily after E12.5. Although AChR cluster area and endplate band width remained abnormal in LiCl-treated HSA$Y_{a p^{-1-}}$ mice (Fig. $9 A-D$ ), the length of secondary nerve branches was shorter in LiCl-treated than saline-treated mutant mice (176 $\pm 25 \mu \mathrm{m}$ in saline control and $130 \pm 35 \mu \mathrm{m}$ in LiCl-treated; $p=0.028, N=6$ mice per group) (Fig. $9 F$ ). LiCl treatment also increased nerve coverage of AChR clusters in $\mathrm{HSA}-\mathrm{Yap}^{-1-}$ mice (from $0.75 \pm 0.07$ in saline-treated HSA-Yap ${ }^{-1-}$ to $0.90 \pm 0.05$ in LiCl-treated mutant; $p=0.0023, N=6$ mice per group; Fig. $9 G$ ).
In addition, mEPP frequency was rescued by $\mathrm{LiCl}$ treatment (from $0.60 \pm 0.1 \mathrm{~Hz}$ in saline-treated mutant group to $0.79 \pm$ $0.08 \mathrm{~Hz}$ in LiCl-treated mutant group; $p=0.0058, N=6$ mice per group) (Fig. 9H,I). These observations indicated a partial rescue of NMJ formation deficits in $\mathrm{HSA}-\mathrm{Yap}^{-/-}$mice by $\mathrm{LiCl}$ treatment.

To determine whether NMJ regeneration deficits could be rescued by $\beta$-catenin activation, we treated mice daily with $\mathrm{LiCl}$ $1 \mathrm{~d}$ after nerve transplant. As shown in Figure $9 \mathrm{~K}, \mathrm{~L}$, LiCl treatment increased the NMJs that are fully innervated, which was associated with concomitant reduction of partially innervated NMJs. These observations demonstrate that NMJ formation and regeneration deficits could be partially rescued by $\mathrm{LiCl}$ (or $\beta$-catenin activation) and support the hypothesis that $\beta$-catenin may be a downstream factor for Yap-dependent signaling.

\section{Discussion}

We provide evidence that the NMJ develops inappropriately in the absence of muscle Yap. The major findings of this study are as follows. First, $H S A-Y a p^{-\prime-}$ mice displayed reduced muscle strength, likely due to impaired neuromuscular transmission (Figs. 1, 2). Second, HSA-Yap ${ }^{-1-}$ mice exhibited both postsynaptic and presynaptic deficits in NMJ. For example, AChR clusters were smaller and were distributed in a broader region in the middle of muscle fibers, whereas primary branch of the phrenic nerve was mislocated toward the central cavity and the length of secondary branch was increased. 
Many AChR clusters were not or less covered by nerve terminals; $\mathrm{mEPP}$ frequency was reduced, which was associated with an increase in paired-pulse facilitation (Figs. 3-5). These results indicate defects in NMJ structure and function. Third, the absence of muscle Yap prevented reinnervation of denervated muscle fibers (Fig. 7). Together, these observations consolidate a role of muscle Yap in NMJ formation and regeneration. Mechanistically and fourth, we found that $\beta$-catenin was reduced in the cytoplasm and nucleus of mutant muscles (Fig. $8 F, G$ ), suggesting compromised $\beta$-catenin signaling. Fifth, NMJ formation and regeneration deficits of $H S A-Y a p^{-1-}$ mice were ameliorated by treatment with $\mathrm{LiCl}$ (Fig. 9), further corroborating a role of $\beta$-catenin or Wnt-dependent signaling downstream of Yap to regulate NMJ formation and regeneration.

Wnt signaling has been implicated in NMJ formation in Drosophila and Caenorhabditis elegans (Packard et al., 2002; Korkut and Budnik, 2009). However, whether mammalian NMJ formation or function is regulated in a similar way was unclear. Recently, several players in Wnt pathways were shown to be involved in AChR clustering in culture (Luo et al., 2002; Wang et al., 2003; Zhang et al., 2007). Wnt ligands could stimulate as well as inhibit AChR clustering (Zhang et al., 2012; Barik et al., 2014a). Ablating or increasing $\beta$-catenin in muscles alters not only the size and location of AChR clusters, but also motor nerve differentiation, possibly by controlling the expression of Slit2 (Li et al., 2008; Jaworski and Tessier-Lavigne, 2012; Liu et al., 2012; Wu et al., 2012a, 2015). These observations suggest the involvement of Wnt signaling in mammalian NMJ formation, although how Wnt signaling is regulated remains poorly understood. Intriguingly, MuSK, a receptor tyrosine kinase critical for NMJ formation, has a cysteine-rich domain that is homologous to Wnt receptor Frizzled (Stiegler et al., 2009). However, whether this domain serves as a receptor for Wnt ligands is in debate (Messéant et al., 2015; Remédio et al., 2016).

Recent evidence indicates that Wnt signaling cross talks with Hippo pathways. In the absence of Wnt, inactive YAP retention at cytoplasm contributes to $\beta$-catenin degradation (Imajo et al., 2012; Azzolin et al., 2014), In the presence of Wnt, YAP is activated and dissociated from the $\beta$-catenin complex, which leads to $\beta$-catenin increase, nuclear localization, and transcriptional activation. On the other hand, Wnt noncanonical signaling pathway also inhibits Hippo kinase LATS and activates YAP in a $\mathrm{G} \alpha_{12 / 13^{-}}$ RhoGTPase-dependent manner (Park et al., 2015). In addition to cytoplasmic interaction, YAP is also part of the $\beta$-catenin transcriptional complex to promote the expression of Wnt signaling proteins (Heallen et al., 2011; Varelas and Wrana, 2012). In this study, we investigated the role of Yap in NMJ formation. Although Yap has been implicated in muscle differentiation in an in vitro study (Watt et al., 2015), myogenic factor levels, muscle fiber type, and size were not significantly different between control and HSA-Yap ${ }^{-1-}$ mice. In agreement, AChR levels were not altered by muscle Yap mutation. A parsimonious interpretation of postsynaptic deficits in HSA-Yap ${ }^{-1-}$ mutant mice (reduced AChR cluster area and increased endplate band width) is therefore that muscle Yap regulates AChR clustering. How Yap does it demands further investigation. Increased endplate band width and axon arborization occur in mice lacking $\gamma$ subunit of AChR (Liu et al., 2010). However, mRNAs of AChR subunits, including $\gamma$, were not reduced in Yap mutant mice during embryonic development (data not shown), suggesting that NMJ abnormality in Yap mutation may not be caused by $\gamma$ deficiency.

Unlike Slit2, whose expression was reduced, levels of Gdnf, Gdf5, and Fgf10 were increased in HSA-Yap ${ }^{-1-}$ mice. However, the mutant mice did not exhibit poly-innervation phenotype as observed in Gdnf gain-of-function mice (Oppenheim et al., 1995; Keller-Peck et al., 2001), Fgf22 was shown to promote presynaptic differentiation in vivo for mossy fibers in the cerebellum and neuromuscular synapse (Umemori et al., 2004; Fox et al., 2007). However, Fgf22 was not altered in $\mathrm{HSA}-\mathrm{Yap}^{-1-}$ muscles, excluding its contribution to observed presynaptic deficits. Whether Fgf10 and Gdf5 regulates NMJ formation warrants further studies. NMJ deficits in HSA-Yap ${ }^{-1-}$ mice were not fully rescued by $\mathrm{LiCl}$ treatment, suggesting that $\beta$-catenin may not be a sole downstream effector of Yap. Recent evidence indicates that Yap could regulate RhoGTPase and basal lamina (Sorrentino et al., 2014; Poitelon et al., 2016), both of which contribute to NMJ formation and maintenance (Noakes et al., 1995; Weston et al., 2000, 2003; Nizhynska et al., 2007; Nishimune et al., 2008).

\section{References}

Arpke RW, Darabi R, Mader TL, Zhang Y, Toyama A, Lonetree CL, Nash N, Lowe DA, Perlingeiro RC, Kyba M (2013) A new immuno-, dystrophindeficient model, the NSG-mdx $(4 \mathrm{Cv})$ mouse, provides evidence for functional improvement following allogeneic satellite cell transplantation. Stem Cells 31:1611-1620. CrossRef Medline

Azzolin L, Panciera T, Soligo S, Enzo E, Bicciato S, Dupont S, Bresolin S, Frasson C, Basso G, Guzzardo V, Fassina A, Cordenonsi M, Piccolo S (2014) YAP/TAZ incorporation in the beta-catenin destruction complex orchestrates the Wnt response. Cell 158:157-170. CrossRef Medline

Barik A, Zhang B, Sohal GS, Xiong WC, Mei L (2014a) Crosstalk between Agrin and Wnt signaling pathways in development of vertebrate neuromuscular junction. Dev Neurobiol 74:828-838. CrossRef Medline

Barik A, Lu Y, Sathyamurthy A, Bowman A, Shen C, Li L, Xiong WC, Mei L (2014b) LRP4 is critical for neuromuscular junction maintenance. J Neurosci 34:13892-13905. CrossRef Medline

Baudet C, Pozas E, Adameyko I, Andersson E, Ericson J, Ernfors P (2008) Retrograde signaling onto Ret during motor nerve terminal maturation. J Neurosci 28:963-975. CrossRef Medline

Bergamin E, Hallock PT, Burden SJ, Hubbard SR (2010) The cytoplasmic adaptor protein Dok7 activates the receptor tyrosine kinase MuSK via dimerization. Mol Cell 39:100-109. CrossRef Medline

Brennan KJ, Hardeman EC (1993) Quantitative analysis of the human alpha-skeletal actin gene in transgenic mice. J Biol Chem 268:719-725. Medline

Chen F, Qian L, Yang ZH, Huang Y, Ngo ST, Ruan NJ, Wang J, Schneider C, Noakes PG, Ding YQ, Mei L, Luo ZG (2007) Rapsyn interaction with calpain stabilizes AChR clusters at the neuromuscular junction. Neuron 55:247-260. CrossRef Medline

Chen F, Liu Y, Sugiura Y, Allen PD, Gregg RG, Lin W (2011) Neuromuscular synaptic patterning requires the function of skeletal muscle dihydropyridine receptors. Nat Neurosci 14:570-577. CrossRef Medline

Cohen I, Rimer M, Lømo T, McMahan UJ (1997) Agrin-induced postsynaptic-like apparatus in skeletal muscle fibers in vivo. Mol Cell Neurosci 9:237-253. CrossRef Medline

Darabid H, Perez-Gonzalez AP, Robitaille R (2014) Neuromuscular synaptogenesis: coordinating partners with multiple functions. Nat Rev Neurosci 15:703-718. Medline

DeChiara TM, Bowen DC, Valenzuela DM, Simmons MV, Poueymirou WT, Thomas S, Kinetz E, Compton DL, Rojas E, Park JS, Smith C, DiStefano PS, Glass DJ, Burden SJ, Yancopoulos GD (1996) The receptor tyrosine kinase MuSK is required for neuromuscular junction formation in vivo. Cell 85:501-512. CrossRef Medline

Fox MA, Sanes JR, Borza DB, Eswarakumar VP, Fässler R, Hudson BG, John SW, Ninomiya Y, Pedchenko V, Pfaff SL, Rheault MN, Sado Y, Segal Y, Werle MJ, Umemori H (2007) Distinct target-derived signals organize formation, maturation, and maintenance of motor nerve terminals. Cell 129:179-193. CrossRef Medline

Fu AK, Ip FC, Fu WY, Cheung J, Wang JH, Yung WH, Ip NY (2005) Aberrant motor axon projection, acetylcholine receptor clustering, and neurotransmission in cyclin-dependent kinase 5 null mice. Proc Natl Acad Sci U S A 102:15224-15229. CrossRef Medline

Gautam M, Noakes PG, Mudd J, Nichol M, Chu GC, Sanes JR, Merlie JP (1995) Failure of postsynaptic specialization to develop at neuromuscu- 
lar junctions of rapsyn-deficient mice. Nature 377:232-236. CrossRef Medline

Heallen T, Zhang M, Wang J, Bonilla-Claudio M, Klysik E, Johnson RL, Martin JF (2011) Hippo pathway inhibits Wnt signaling to restrain cardiomyocyte proliferation and heart size. Science 332:458-461. CrossRef Medline

Imajo M, Miyatake K, Iimura A, Miyamoto A, Nishida E (2012) A molecular mechanism that links Hippo signalling to the inhibition of Wnt/betacatenin signalling. EMBO J 31:1109-1122. CrossRef Medline

Ingalls CP, Warren GL, Zhang JZ, Hamilton SL, Armstrong RB (2004) Dihydropyridine and ryanodine receptor binding after eccentric contractions in mouse skeletal muscle. J Appl Physiol 96:1619-1625. CrossRef Medline

Jaworski A, Tessier-Lavigne M (2012) Autocrine/juxtaparacrine regulation of axon fasciculation by Slit-Robo signaling. Nat Neurosci 15:367-369. CrossRef Medline

Keller-Peck CR, Feng G, Sanes JR, Yan Q, Lichtman JW, Snider WD (2001) Glial cell line-derived neurotrophic factor administration in postnatal life results in motor unit enlargement and continuous synaptic remodeling at the neuromuscular junction. J Neurosci 21:6136-6146. Medline

Kim N, Stiegler AL, Cameron TO, Hallock PT, Gomez AM, Huang JH, Hubbard SR, Dustin ML, Burden SJ (2008) Lrp4 is a receptor for Agrin and forms a complex with MuSK. Cell 135:334-342. CrossRef Medline

Korkut C, Budnik V (2009) WNTs tune up the neuromuscular junction. Nat Rev Neurosci 10:627-634. CrossRef Medline

Liang C, Tao Y, Shen C, Tan Z, Xiong WC, Mei L (2012) Erbin is required for myelination in regenerated axons after injury. J Neurosci 32:1516915180. CrossRef Medline

Li XM, Dong XP, Luo SW, Zhang B, Lee DH, Ting AK, Neiswender H, Kim CH, Carpenter-Hyland E, Gao TM, Xiong WC, Mei L (2008) Retrograde regulation of motoneuron differentiation by muscle beta-catenin. Nat Neurosci 11:262-268. CrossRef Medline

Lin W, Burgess RW, Dominguez B, Pfaff SL, Sanes JR, Lee KF (2001) Distinct roles of nerve and muscle in postsynaptic differentiation of the neuromuscular synapse. Nature 410:1057-1064. CrossRef Medline

Lin W, Dominguez B, Yang J, Aryal P, Brandon EP, Gage FH, Lee KF (2005) Neurotransmitter acetylcholine negatively regulates neuromuscular synapse formation by a Cdk5-dependent mechanism. Neuron 46:569-579. CrossRef Medline

Liu Y, Sugiura Y, Padgett D, Lin W (2010) Postsynaptic development of the neuromuscular junction in mice lacking the gamma-subunit of muscle nicotinic acetylcholine receptor. J Mol Neurosci 40:21-26. CrossRef Medline

Liu Y, Sugiura Y, Wu F, Mi W, Taketo MM, Cannon S, Carroll T, Lin W (2012) $\beta$-Catenin stabilization in skeletal muscles, but not in motor neurons, leads to aberrant motor innervation of the muscle during neuromuscular development in mice. Dev Biol 366:255-267. CrossRef Medline

Luo ZG, Wang Q, Zhou JZ, Wang J, Luo Z, Liu M, He X, Wynshaw-Boris A, Xiong WC, Lu B, Mei L (2002) Regulation of AChR clustering by Dishevelled interacting with MuSK and PAK1. Neuron 35:489-505. CrossRef Medline

Macpherson PC, Farshi P, Goldman D (2015) Dach2-Hdac9 signaling regulates reinnervation of muscle endplates. Development 142:4038-4048. CrossRef Medline

Messéant J, Dobbertin A, Girard E, Delers P, Manuel M, Mangione F, Schmitt A, Le Denmat D, Molgó J, Zytnicki D, Schaeffer L, Legay C, Strochlic L (2015) MuSK frizzled-like domain is critical for mammalian neuromuscular junction formation and maintenance. J Neurosci 35:4926-4941. CrossRef Medline

Miniou P, Tiziano D, Frugier T, Roblot N, Le Meur M, Melki J (1999) Gene targeting restricted to mouse striated muscle lineage. Nucleic Acids Res 27:e27. CrossRef Medline

Mitsumoto H, Bradley WG (1982) Murine motor neuron disease (the wobbler mouse): degeneration and regeneration of the lower motor neuron. Brain 105:811-834. CrossRef Medline

Morin-Kensicki EM, Boone BN, Howell M, Stonebraker JR, Teed J, Alb JG, Magnuson TR, O’Neal W, Milgram SL (2006) Defects in yolk sac vasculogenesis, chorioallantoic fusion, and embryonic axis elongation in mice with targeted disruption of Yap65. Mol Cell Biol 26:77-87. CrossRef Medline

Nelson BR, Wu F, Liu Y, Anderson DM, McAnally J, Lin W, Cannon SC, Bassel-Duby R, Olson EN (2013) Skeletal muscle-specific T-tubule pro- tein STAC3 mediates voltage-induced $\mathrm{Ca}^{2+}$ release and contractility. Proc Natl Acad Sci U S A 110:11881-11886. CrossRef Medline

Nishimune H, Valdez G, Jarad G, Moulson CL, Müller U, Miner JH, Sanes JR (2008) Laminins promote postsynaptic maturation by an autocrine mechanism at the neuromuscular junction. J Cell Biol 182:1201-1215. CrossRef Medline

Nishioka N, Inoue K, Adachi K, Kiyonari H, Ota M, Ralston A, Yabuta N, Hirahara S, Stephenson RO, Ogonuki N, Makita R, Kurihara H, MorinKensicki EM, Nojima H, Rossant J, Nakao K, Niwa H, Sasaki H (2009) The Hippo signaling pathway components Lats and Yap pattern Tead4 activity to distinguish mouse trophectoderm from inner cell mass. Dev Cell 16:398-410. CrossRef Medline

Nizhynska V, Neumueller R, Herbst R (2007) Phosphoinositide 3-kinase acts through RAC and Cdc42 during agrin-induced acetylcholine receptor clustering. Dev Neurobiol 67:1047-1058. CrossRef Medline

Noakes PG, Gautam M, Mudd J, Sanes JR, Merlie JP (1995) Aberrant differentiation of neuromuscular junctions in mice lacking s-laminin/ laminin beta 2. Nature 374:258-262. CrossRef Medline

Okada K, Inoue A, Okada M, Murata Y, Kakuta S, Jigami T, Kubo S, Shiraishi H, Eguchi K, Motomura M, Akiyama T, Iwakura Y, Higuchi O, Yamanashi Y (2006) The muscle protein Dok-7 is essential for neuromuscular synaptogenesis. Science 312:1802-1805. CrossRef Medline

Oppenheim RW, Prevette D, Haverkamp LJ, Houenou L, Yin QW, McManaman J (1993) Biological studies of a putative avian muscle-derived neurotrophic factor that prevents naturally occurring motoneuron death in vivo. J Neurobiol 24:1065-1079. CrossRef Medline

Oppenheim RW, Houenou LJ, Johnson JE, Lin LF, Li L, Lo AC, Newsome AL, Prevette DM, Wang S (1995) Developing motor neurons rescued from programmed and axotomy-induced cell death by GDNF. Nature 373: 344-346. CrossRef Medline

Packard M, Koo ES, Gorczyca M, Sharpe J, Cumberledge S, Budnik V (2002) The Drosophila Wnt, wingless, provides an essential signal for presynaptic and postsynaptic differentiation. Cell 111:319-330. CrossRef Medline

Park HW, Kim YC, Yu B, Moroishi T, Mo JS, Plouffe SW, Meng Z, Lin KC, Yu FX, Alexander CM, Wang CY, Guan KL (2015) Alternative Wnt signaling activates YAP/TAZ. Cell 162:780-794. CrossRef Medline

Payne SH Jr, Brushart TM (1997) Neurotization of the rat soleus muscle: a quantitative analysis of reinnervation. J Hand Surg Am 22:640-643. CrossRef Medline

Phillips WD, Kopta C, Blount P, Gardner PD, Steinbach JH, Merlie JP (1991) ACh receptor-rich membrane domains organized in fibroblasts by recombinant 43-kildalton protein. Science 251:568-570. CrossRef Medline

Poitelon Y, Lopez-Anido C, Catignas K, Berti C, Palmisano M, Williamson C, Ameroso D, Abiko K, Hwang Y, Gregorieff A, Wrana JL, Asmani M, Zhao R, Sim FJ, Wrabetz L, Svaren J, Feltri ML (2016) YAP and TAZ control peripheral myelination and the expression of laminin receptors in Schwann cells. Nat Neurosci 19:879-887. CrossRef Medline

Remédio L, Gribble KD, Lee JK, Kim N, Hallock PT, Delestrée N, Mentis GZ, Froemke RC, Granato M, Burden SJ (2016) Diverging roles for Lrp4 and Wnt signaling in neuromuscular synapse development during evolution. Genes Dev 30:1058-1069. CrossRef Medline

Sanes JR, Lichtman JW (2001) Induction, assembly, maturation and maintenance of a postsynaptic apparatus. Nat Rev Neurosci 2:791-805. CrossRef Medline

Santos D, Giudetti G, Micera S, Navarro X, del Valle J (2016) Focal release of neurotrophic factors by biodegradable microspheres enhance motor and sensory axonal regeneration in vitro and in vivo. Brain Res 1636:93-106. CrossRef Medline

Schwander M, Leu M, Stumm M, Dorchies OM, Ruegg UT, Schittny J, Müller U (2003) Betal integrins regulate myoblast fusion and sarcomere assembly. Dev Cell 4:673-685. CrossRef Medline

Shen C, Lu Y, Zhang B, Figueiredo D, Bean J, Jung J, Wu H, Barik A, Yin DM, Xiong WC, Mei L (2013) Antibodies against low-density lipoprotein receptor-related protein 4 induce myasthenia gravis. J Clin Invest 123: 5190-5202. CrossRef Medline

Sorrentino G, Ruggeri N, Specchia V, Cordenonsi M, Mano M, Dupont S, Manfrin A, Ingallina E, Sommaggio R, Piazza S, Rosato A, Piccolo S, Del Sal G (2014) Metabolic control of YAP and TAZ by the mevalonate pathway. Nat Cell Biol 16:357-366. CrossRef Medline

Stiegler AL, Burden SJ, Hubbard SR (2009) Crystal structure of the frizzledlike cysteine-rich domain of the receptor tyrosine kinase MuSK. J Mol Biol 393:1-9. CrossRef Medline 
Tintignac LA, Brenner HR, Rüegg MA (2015) Mechanisms regulating neuromuscular junction development and function and causes of muscle wasting. Physiol Rev 95:809-852. CrossRef Medline

Umemori H, Linhoff MW, Ornitz DM, Sanes JR (2004) FGF22 and its close relatives are presynaptic organizing molecules in the mammalian brain. Cell 118:257-270. CrossRef Medline

van der Ven PF, Schaart G, Jap PH, Sengers RC, Stadhouders AM, Ramaekers FC (1992) Differentiation of human skeletal muscle cells in culture: maturation as indicated by titin and desmin striation. Cell Tissue Res 270:189-198. CrossRef Medline

Varelas X, Wrana JL (2012) Coordinating developmental signaling: novel roles for the Hippo pathway. Trends Cell Biol 22:88-96. CrossRef Medline

Wang J, Jing Z, Zhang L, Zhou G, Braun J, Yao Y, Wang ZZ (2003) Regulation of acetylcholine receptor clustering by the tumor suppressor APC. Nat Neurosci 6:1017-1018. CrossRef Medline

Wang Y, Hu G, Liu F, Wang X, Wu M, Schwarz JJ, Zhou J (2014) Deletion of yes-associated protein (YAP) specifically in cardiac and vascular smooth muscle cells reveals a crucial role for YAP in mouse cardiovascular development. Circ Res 114:957-965. CrossRef Medline

Watt KI, Turner BJ, Hagg A, Zhang X, Davey JR, Qian H, Beyer C, Winbanks CE, Harvey KF, Gregorevic P (2015) The Hippo pathway effector YAP is a critical regulator of skeletal muscle fibre size. Nat Commun 6:6048. CrossRef Medline

Weston C, Yee B, Hod E, Prives J (2000) Agrin-induced acetylcholine receptor clustering is mediated by the small guanosine triphosphatases Rac and Cdc42. J Cell Biol 150:205-212. CrossRef Medline

Weston C, Gordon C, Teressa G, Hod E, Ren XD, Prives J (2003) Cooperative regulation by Rac and Rho of agrin-induced acetylcholine receptor clustering in muscle cells. J Biol Chem 278:6450-6455. CrossRef Medline
Wu H, Xiong WC, Mei L (2010) To build a synapse: signaling pathways in neuromuscular junction assembly. Development 137:1017-1033. CrossRef Medline

Wu H, Lu Y, Barik A, Joseph A, Taketo MM, Xiong WC, Mei L (2012a) $\beta$-Catenin gain of function in muscles impairs neuromuscular junction formation. Development 139:2392-2404. CrossRef Medline

Wu H, Lu Y, Shen C, Patel N, Gan L, Xiong WC, Mei L (2012b) Distinct roles of muscle and motoneuron LRP4 in neuromuscular junction formation. Neuron 75:94-107. CrossRef Medline

Wu H, Barik A, Lu Y, Shen C, Bowman A, Li L, Sathyamurthy A, Lin TW, Xiong WC, Mei L (2015) Slit2 as a beta-catenin/Ctnnb1-dependent retrograde signal for presynaptic differentiation. eLife 4.

Yang J, Dominguez B, de Winter F, Gould TW, Eriksson JE, Lee KF (2011) Nestin negatively regulates postsynaptic differentiation of the neuromuscular synapse. Nat Neurosci 14:324-330. CrossRef Medline

Zhang B, Luo S, Dong XP, Zhang X, Liu C, Luo Z, Xiong WC, Mei L (2007) $\beta$-Catenin regulates acetylcholine receptor clustering in muscle cells through interaction with rapsyn. J Neurosci 27:3968-3973. CrossRef Medline

Zhang B, Luo S, Wang Q, Suzuki T, Xiong WC, Mei L (2008) LRP4 serves as a coreceptor of agrin. Neuron 60:285-297. CrossRef Medline

Zhang B, Liang C, Bates R, Yin Y, Xiong WC, Mei L (2012) Wnt proteins regulate acetylcholine receptor clustering in muscle cells. Mol Brain 5:7. CrossRef Medline

Zhang N, Bai H, David KK, Dong J, Zheng Y, Cai J, Giovannini M, Liu P, Anders RA, Pan D (2010) The Merlin/NF2 tumor suppressor functions through the YAP oncoprotein to regulate tissue homeostasis in mammals. Dev Cell 19:27-38. CrossRef Medline 